
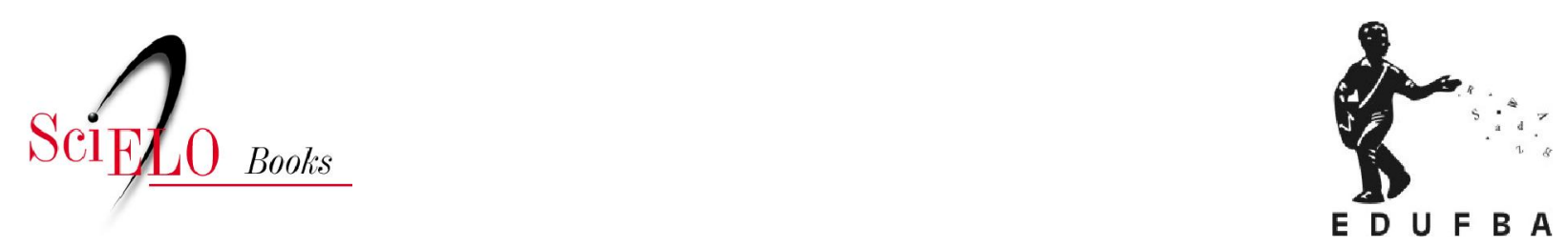

\title{
Dos vinte réis aos vinte centavos o papel das redes sociais e movimentos coletivos no Brasil
}

\author{
José Antonio Gomes de Pinho \\ Ingrid Winkler \\ Júlio César Andrade de Abreu \\ Fabiano Maury Raupp
}

\section{SciELO Books / SciELO Livros / SciELO Libros}

PINHO, J.A.G., WINKLER, I., ABREU, J.C.A., and RAUPP, F.M. Dos vinte réis aos vinte centavos: o papel das redes sociais e movimentos coletivos no Brasil. In: PINHO, J.A.G., ed. Artefatos digitais para mobilização da sociedade civil: perspectivas para avanço da democracia [online]. Salvador: EDUFBA, 2016, pp. 169-221. ISBN: 978-85-232-1877-5. https://doi.org/10.7476/9788523218775.0009.

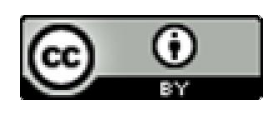

All the contents of this work, except where otherwise noted, is licensed under a Creative Commons Attribution $\underline{4.0 \text { International license. }}$

Todo o conteúdo deste trabalho, exceto quando houver ressalva, é publicado sob a licença Creative Commons Atribição 4.0.

Todo el contenido de esta obra, excepto donde se indique lo contrario, está bajo licencia de la licencia Creative Commons Reconocimento 4.0. 


\title{
DOS VINTE RÉIS AOS VINTE CENTAVOS
}

\author{
o papel das redes sociais e movimentos \\ coletivos no Brasil
}

JOSÉ ANTONIO GOMES DE PINHO, INGRID WINKLER, JÚLIO CÉSAR ANDRADE DE ABREU, FABIANO MAURY RAUPP

\section{INTRODUÇÃO}

Este artigo versa sobre as manifestações de protesto ocorridas no Brasil a partir de junho de 2013 (daqui para frente, chamadas de junho/13) e a dois outros momentos onde ocorreram manifestações populares: o movimento Fora Sarney (FS), na versão transcorrida em Salvador em 2009 e a longínqua Revolta do Vintém (RV), que explodiu no final de 1879 e começo de 1880, última década do Império. Nos dois primeiros casos, o artigo bosqueja o papel das tecnologias digitais com ênfase nas redes sociais. O objetivo do artigo é entender não só como estas ocorreram, mas também o seu, digamos, "making of", como os participantes foram mobilizados em tempos de prevalência de recursos digitais, a saber, as chamadas redes sociais, no caso em que se aplicam. De imediato faz-se necessário perguntar o que teriam em comum esses movimentos, ainda mais quanto a esta última, levando em conta que já se passou bem mais do que um século entre a Revolta do Vintém e os outros dois acontecimentos aqui contemplados. 
Podemos assim notar diferentes correlações entre estes três eventos, que indicamos na Figura 1. O que tem de comum entre a RV e as manifestações de junho/13 (área 3 na Figura 1) é a luta contra o aumento das passagens do transporte público, esse é o liame entre a RV e o Junho/13. A título de curiosidade, o número " 20 " também esteve presente em ambas as manifestações. Enquanto os " 20 centavos" foi o estopim das manifestações de Junho/13, os "vinte réis", ou seja, um vintém, motivaram a RV. Por sua vez, o que existe de comum entre o FS e o junho/13 (área 2, na Figura 1) é o uso intensivo de recursos digitais, não constando na agenda a contestação do aumento das passagens de transporte público. Uma outra diferença ainda tem que ser apontada entre esses dois momentos. O FS primava pelo combate à corrupção entronizada na figura do Senador José Sarney e uma tentativa de cassação de seu mandato em curso naquela época no Congresso, enquanto as manifestações mais recentes partiram da questão da tarifa do transporte, mas logo desembocaram em um grande continente de demandas diversificadas, emergindo, com primazia, a luta contra a corrupção e insatisfação com as prioridades governamentais (sobretudo, as obras da Copa do Mundo de futebol no Brasil) e o próprio desempenho governamental. Poder-se-ia afirmar que o FS era mais focado no combate à corrupção e a uma das figuras emblemáticas do fenômeno, o senador Sarney, enquanto a pauta de junho/13 era mais dispersa e difusa, mas também passando a conter o combate à corrupção. Já a RV e o FS (área 1, na figura) não guardam semelhanças, além de serem manifestações populares contra desmandos governamentais que prejudicaram diretamente a população (aumento de tributos e corrupção). Seus contextos, motivações e características são bem distintos, mas, ainda assim, nos dão uma interessante dimensão para análise e contraste neste trabalho.

Se não existem grandes diferenças de contexto entre o FS de 2009 e as manifestações de junho/13, as diferenças entre o contexto da RV e as mais recentes (2009 e 2013) são, obviamente, imensas. O que se pode perceber é que existem aproximações e distanciamentos entre os três movimentos, sem embargo do tempo transcorrido entre o mo- 
vimento do final do Império e os mais recentes. Em outras palavras, mesmo passados mais de 130 anos da RV ainda é possível aprender com aquele fenômeno para entender os dias de hoje e até mesmo o futuro próximo.

Figura 1 - Correlações entre os eventos RV, FS e junho/13

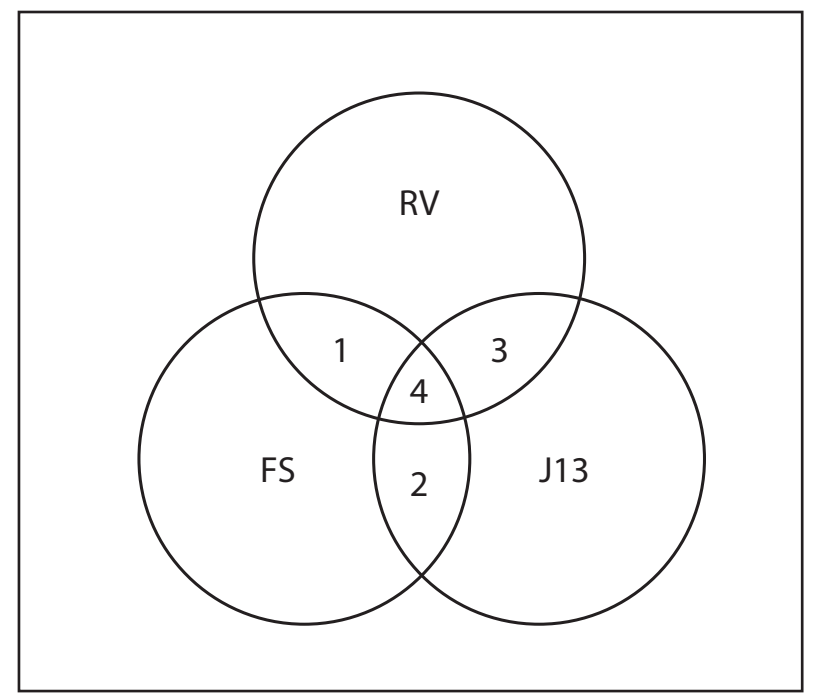

Fonte: elaborado pelos próprios autores.

Metodologicamente, iremos começar pelos movimentos mais recentes, pois são os que mobilizam mais e que estão no foco dos pesquisadores e observadores da cena política nacional. Os dois outros movimentos considerados serão contraponto ao que ocorre contemporaneamente.

Antes de iniciarmos a apresentação e reflexão dos acontecimentos iniciados em junho de 2013, é de bom alvitre fazer algumas considerações que nos levam a relativizar a importância e magnitude dos mesmos, ainda que não passe pela cabeça de ninguém negar a importância e impacto dessas ocorrências (que evidentemente ainda não podem ser sentidos em toda sua extensão, ainda que tenham reverberado ao longo de 2014). Assim, uma primeira consideração ou alerta a ser feito se refere ao fato de certa interpretação de ineditismo desses 
movimentos recentes. Este alerta tem dois braços. O primeiro aponta que esses movimentos recentes são precedidos de outros tais, como o próprio FS e outros de maior porte e impacto, como o dos Caras Pintadas (1992), e o maior de todos ocorrido no Brasil, o movimento das Diretas-Já (1984). Dessa juntada podemos extrair que o Brasil se move de forma espasmódica em relação a movimentos sociais de grande porte e consequências. Se o Diretas-Já foi derrotado, o Caras Pintadas contribuiu decisivamente para o impeachment do presidente Collor, objetivo do movimento. O segundo braço repousa na constatação de um sem número de movimentos, rebeliões, revoltas e protestos que ocorrem molecularmente no país, tanto no meio urbano como no meio rural, e que, em geral, não conseguem chegar ao proscênio porque se localizam na periferia das cidades de um modo geral. As motivações dessas manifestações são as mais diversas: revolta por morte de algum morador em comunidades por atropelamento, no qual a demanda normalmente reivindicada é a construção de passarelas sobre as estradas, revolta por ação da polícia matando algum/a morador/a da comunidade, revolta por falta de segurança pública, de educação, saúde etc. Ainda revolta por desocupação de conjuntos habitacionais ou reintegração de posse de alguma área ocupada, invadida. Muitas dessas manifestações contêm elementos fortes de violência, tais como fechamento de ruas, construção de barricadas com queima de pneus, árvores e lixo. Essas manifestações só não ganham maior expressão porque acontecem, em geral, na periferia, onde as carências da população saltam aos olhos e tem um caráter mais de explosão, revolta não se sustentando no tempo. O que queremos enfatizar com essa apresentação é que o povo, principalmente na periferia, tem uma posição praticamente ativa, se não durante o tempo todo, pelo menos com uma frequência que normalmente não é percebida. O que se deseja enfatizar é que não estamos exatamente frente a uma sociedade completamente passiva que não esboça nenhuma reação. A sociedade reage, sim, mas, em geral, de forma tópica, sem maior estruturação e organização e sem continuidade. 
Por outro lado, quando o movimento ocorre em uma área central e/ou nobre, passa a chamar a atenção, e mais ainda se é realizado não por periféricos, mas por pessoas mais bem situadas na escala social. No caso específico do detonador dos movimentos mais recentes, vale notar que havia toda uma pretérita construção de luta contra o aumento das passagens dos ônibus com as explosões da Revolta do Buzu em Salvador (2003) e também da Revolta das Catracas em Florianópolis (2004). Em outras palavras, o Movimento do Passe Livre (MPL) não surgiu do nada, não aconteceu de uma hora para outra, veio de uma construção histórica de luta no segmento do transporte público.

A compreensão dos movimentos de junho/13 pode ser buscada em duas fontes fundamentalmente. Uma primeira consiste nos escritos feitos no calor dos acontecimentos, normalmente respirando muito otimismo aliado a ineditismo e surpresa com os acontecimentos. Uma segunda fonte encontra-se em documentos produzidos um pouco além desses primeiros momentos quando os movimentos haviam refluído quando o distanciamento já possibilitava uma visão mais realista, menos otimista e contemplando os desdobramentos que se produziram ao longo do tempo e dentro do movimento. Neste artigo, recorreremos a essas duas fontes.

Nada melhor do que começar exatamente expondo o pensamento do MPL. No calor dos acontecimentos, o MPL produz um texto que pode ser encarado como um manifesto onde descreve, de maneira sucinta e direta, sua trajetória e teleologia, contribuição central ao entendimento de todo esse processo. O projeto do MPL (2013, p. 13-15) é ambicioso, partindo do princípio de que "[...] o transporte é ordenado de cima para baixo, segundo os imperativos da circulação do valor". $\mathrm{Na}$ luta contra a exclusão urbana é que "[...] se forjou o Movimento Passe Livre”. O documento registra o que é sobejamente conhecido: que para compreender o processo que levou às "revoltas de junho de 2013", é necessário recuar no tempo, pelo menos até a chamada "Revolta do Buzu”, ocorrida em Salvador, em 2003, como resposta ao aumento das passagens dos ônibus. As estimativas de participação indicam $40 \mathrm{mil}$ pessoas a partir de "[...] estudantes secundaristas" com um modelo 
de organização “[...] afastado dos modelos hierarquizados”. Esta experiência ganhou reconhecimento nacional estourando no ano seguinte, 2004, em Florianópolis gerando protestos que “[...] forçaram o poder público a revogar o aumento e serviram de base para a fundação do MPL no ano seguinte”. Pode-se perceber assim que quando os eventos de junho de 2013 ocorreram a partir de São Paulo, o MPL já amealhava uma experiência de oito anos.

O MPL surge como um movimento social "[...] horizontal e apartidário, cujos coletivos locais, federados, não se submetem a qualquer organização central”. As deliberações são tomadas “[...] de baixo, por todos, em espaços que não possuem dirigentes, nem respondem a qualquer instância externa superior”. Para o Movimento, “[...] a maior parte da população explorada nos ônibus” não tem dinheiro suficiente para a condução além dos deslocamentos “[...] entre a casa, na periferia, e o trabalho, no centro”. O Movimento ainda explica que a inserção dos trabalhadores na "reapropriação do espaço urbano" vem a superar “[...] a bandeira do MPL em seus primeiros anos, que era o passe livre estudantil”. Enquanto estratégia, o MPL entende que a cidade é “[...] usada como arma para sua própria retomada" ao promover o bloqueio de "um mero cruzamento" que compromete toda a circulação, devido ao fato da predominância do transporte individual nas vias. Na percepção do Movimento, foi isto que ocorreu em São Paulo em junho/13 e que levou o prefeito a revogar o aumento da passagem em vinte centavos (e o governador a não implantar o aumento no metrô e nos trens). E esta medida propagou-se “[...] em mais de cem cidades do país" quando “[...] as pessoas deslocaram momentaneamente - e com impactos duradouros - o controle político da gestão do transporte". O documento se encerra com a afirmação de que essas "[...] mobilizações sempre foram muito mais amplas que o Movimento Passe Livre - que jamais se pretendeu dono de qualquer uma delas - e eclodiram, por vezes, em cidades e regiões onde nunca houve atividade do movimento". A partir dessas mobilizações de junho/13, "[...] milhares continuam nas ruas em diversas cidades, defendendo agora a implementação da tarifa zero". (MARICATO et al., 2013, p. 16-17) 
O movimento em si pode ser visto como tendo pelo menos quatro fases: 1) as manifestações iniciais, notadamente em São Paulo, com a presença de um número relativamente pequeno de participantes; 2) a reação da polícia, marcada por extrema violência, o que resultou, talvez ao contrário do esperado, em um fortalecimento dos movimentos e seu espalhamento para outras cidades do país; 3) o recuo das autoridades, cancelando o aumento previsto do transporte público bem como o recuo da ação violenta da polícia, o que gerou mais um fortalecimento das manifestações: 4) a entrada em cena dos Black blocs o que provocou, não de imediato, mas no curto prazo, a retirada do MPL e de manifestantes, esvaziando as manifestações. A esse respeito vale a pena resgatar uma expressão lembrada por Umberto Eco ao comentar a participação da juventude na vida política, qual seja, "[...] todos nascemos incendiários e morremos bombeiros". (ECO, 2008) Incendiários e bombeiros são figuras metafóricas, mas aplicando esse pensamento aos eventos de junho/13, pode-se perceber que quando chegaram os verdadeiros incendiários nas manifestações, os Black blocs, jovens incendiários metafóricos, tentaram dissuadir este grupo do uso da violência. Assim, foram bombeiros ainda jovens, mostrando que a raiz dos protestos tinha, em geral, um caráter pacifista.

\section{REFERENCIAL TEÓRICO}

O referencial teórico deste artigo possui duas vertentes: uma que examina a questão dos movimentos em si, com ênfase nas chamadas jornadas de junho/13, e nas possibilidades de uso das redes sociais para ensejar uma nova forma de fazer política nas condições contemporâneas.

\section{Internet, as redes sociais e a Política no Brasil}

Começando por esta última, uma questão central que a Internet e, principalmente, as redes sociais têm suscitado é até que ponto todas essas ferramentas podem mudar a forma tradicional de fazer política por parte da sociedade civil, gerando um upgrade e, assim, mudando o quadro político existente? Não resta dúvida de que a Internet e as redes reúnem 
condições intrínsecas de promover uma participação maior da sociedade e por suas facilidades de contato, funcionamento permanente e on-line, mobilizar mais pessoas, trazê-las mais para perto, ainda que no mundo digital. Por outro lado, outras questões têm que ser levantadas sobre a política em si. Assim, cabe perguntar: se uma sociedade civil não se mobiliza pelos canais convencionais e tradicionais, produzindo uma participação política mais ativa, será que iria, agora, ao usar os recursos da comunicação digital, gerar uma sociedade mais ativa politicamente? (PINHO, 2011) Participar nas redes sociais é suficiente para produzir mudanças mais efetivas e concretas na esfera política? Ou seria esta fase uma primeira para gerar resultados mais efetivos?

Não há como desmerecer a utilização de recursos digitais na esfera política, tais como urna eletrônica, a possibilidade de fazer petições on-line, envio de mensagens eletrônicas para parlamentares, governantes e setores do Estado, estabelecimento de fóruns para debate de questões políticas. Todas essas, entre outras, representam ações possíveis por conta do meio digital.

Mas, nesta sociedade fundamentalmente digital, estariam esgotadas, superadas as formas mais tradicionais de fazer política? Ao que tudo indica, ainda estamos naquela situação de lusco-fusco da mudança de um padrão tecnológico para outro, mas isto não quer dizer que o antigo padrão não tenha mais espaço. Essa questão ainda comporta uma outra preocupação que conspira contra o caráter democrático das redes face ao caráter elitista, dominante das mídias tradicionais. Assim, a possibilidade dos grupos mais instruídos e com acesso mais fácil às redes monopolizarem movimentos na rede pode produzir uma participação ainda elitista. Este artigo, ao examinar três movimentos distintos, objetiva lançar luz para a busca de respostas para esses questionamentos.

Laymert Garcia dos Santos (2003) pontua que “[...] a tecnologização da sociedade é intensa” observando-se uma centralidade da tecnologia. O autor relembra Lênin que definia o comunismo como os sovietes acrescidos da eletricidade e questiona como seria com a busca do socialismo atual: "Será que podemos substituir a eletricidade pela internet, 
e os sovietes pelas comunidades de base e achar que encaminhamos a questão?" Para fundamentar não uma resposta, mas uma reflexão, vê a questão de uma forma bem complexa, pois seria “[...] ingênuo acharmos que a internet é um território livre, que vamos conseguir fazer uma revolução usando a internet”. Por outro lado, não nega “[...] o aspecto democrático de circulação da informação que existe na internet e as conexões que ela possibilita" visualizando que "[...] existem brechas dentro dos sistemas" que devem ser aproveitadas, mas devendo-se lembrar que a internet é uma tecnologia nova e que "[...] o capital está começando a colonizá-la agora”. Assim, no momento em que houver "[...] uma grande capilaridade nos países industrializados, quando a vida for impossível sem a internet, então aí é que vai começar a regulação da internet”. (SANTOS, 2003, p. 17, 74-75)

Relembra o autor que as tecnologias anteriores foram apresentadas como democráticas, como parte do mito do progresso, mas apresenta sua discordância com o fato de que as novas tecnologias sejam todas para o bem, como não acredita que “[...] os indivíduos sejam todos iguais" constatando diferenças entre um operador do Primeiro Mundo e do Brasil devido às desigualdades educacionais existentes. Como choque de realidade, expõe que "[...] o fato de existir uma rede não significa que ela é necessariamente democrática”. (SANTOS, 2003, p. 76)

Isto posto, o próprio Santos coloca-se como "[...] mais realista do que catastrofista”. Bernardo Kucinskyi, por sua vez, assume uma posição oposta ao entender a revolução da comunicação como "libertária”, exemplificando que com a possibilidade de se produzir um jornal com 3 ou 4 mil reais e assim, a pessoa "[...] libertou-se do capital". Em seu entender, a atual revolução tecnológica vai na direção oposta da revolução industrial do século XVIII que com a máquina transformou cada trabalhador dependente do dono dos bens de produção. Discorda de Santos ao entender que não existe uma propensão ao capital se apropriar de tudo, como no caso das músicas na internet com a produção caseira de CDs. Kucinski defende que as tecnologias modernas "[...] libertam as pessoas dos sistemas", gerando "a autonomia do indivíduo na comunicação”, apontando como natureza dessas 
tecnologias a "[...] interatividade e custo baixíssimo". Ressalta como importante o fato que as novas tecnologias "[...] parecem ter nascido com as novas gerações: está no sangue delas". Converge com Santos, por sua vez, ao constatar a necessidade de "[...] um novo nível de escolaridade”. As novas tecnologias potencializaram as capacidades do produtor intelectual, ressaltando os milhões de acessos diários à internet, bem como "[...] ações de protesto", que aumentam cada vez mais, não se sabendo "[...] aonde isso vai parar" e nem se tendo "[...] a dimensão exata disso". Em suma, “[...] essas tecnologias abrem uma nova possibilidade de libertação. Nós só temos que saber com usá-las". (SANTOS, 2003, p. 54-55, 70, 78, 80, 82)

Alguns comentários parecem pertinentes a partir dessas observações. Não resta dúvida de que muito do que Kucinskyi aponta é verdade, mas não se sente o peso de fazer política de uma forma diferente e efetiva em suas observações. Passados já mais de dez anos dessas reflexões ainda parece que a obra não está terminada (talvez esteja apenas começando) e não seja possível já extrair posições definitivas a respeito da mudança da forma de fazer política, apesar de toda a parafernália de artefatos tecnológicos, até porque a tecnologia muda muito rapidamente, disponibilizando mais opções aos usuários (cidadãos?), enquanto que a política se move na velocidade tradicional. (PINHO, 2008)

$\mathrm{Na}$ linha de argumento de Kucinskyi (2003) Sorj (2003, p. 49, 57), posiciona que "[...] a Internet é relacionada a uma nova forma de fazer política, dissociada ou à margem do Estado, pelo fortalecimento das redes da sociedade civil”, ponderando, no entanto, que não existam, até o momento, "[...] elementos suficientes que confirmem qualquer suposição sobre o impacto da Internet na política”, convergindo com o dito acima. Os novos recursos digitais podem promover uma transformação radical da democracia representativa em democracia plebiscitária, a partir do aumento da participação dos cidadãos nas decisões dos governos, através do voto eletrônico. Indo um pouco além, a internet permite "[...] radicalizar a democracia, criando um novo espaço público construído em torno de uma sociedade civil que se organizará à margem do Estado". Por outro lado, vendo a questão de um prisma pes- 
simista, “[...] a nova sociabilidade virtual destrói as bases da interação que permite a construção do espaço público e aumenta a capacidade de controle da população pelo Estado". Nesta corrente, “[...] a internet destrói as relações face a face, que seria a única fonte de comunicação capaz de gerar grupos sólidos e estáveis, com memória histórica (no lugar do mundo atemporal da internet), que seria a única base possível de sustentação de uma vida pública e de ação política constante”. Nesse contexto, a própria tecnologia cria condições para o controle crescente do Estado e das empresas sobre os cidadãos. Escrevendo um pouco antes, Agre (1997, p. 114) assevera que a internet “[...] oferece a esperança de uma sociedade mais democrática. Através da promoção de uma forma descentralizada de mobilização social, diz-se que a internet pode nos ajudar a renovar nossas instituições e nos libertar de nossos legados autoritários". No entanto, o próprio autor reduz esta expectativa ao ponderar que a internet “[...] detém essas possibilidades, mas elas não são absolutamente inevitáveis”. Mas que isso, pode se transformar em "instrumento de opressão" e de centralização do poder. Em outras palavras, acreditar piamente que a internet vai resolver nossos problemas de democracia é acreditar que se trata de uma luta tecnológica e não uma de luta política.

É interessante nos voltarmos para esta literatura produzida há mais de dez anos e ver quais promessas e expectativas se concretizarem. Apesar do aumento vertiginoso dos artefatos tecnológicos (ainda não havia as redes sociais digitais naquela época), e ainda sobre o aumento da participação nas redes, parece que os reflexos na política e na forma de fazer política não se alteraram substancialmente no caso do Brasil. As estruturas tradicionais e conservadoras da política no Brasil se mantêm sólidas frente aos avanços das tecnologias digitais e do uso delas. A literatura acima exposta levanta as questões referentes à participação digital versus a participação face a face. O raciocínio não é nem uma, nem outra, não é uma ou outra, mas sim uma e outra. Há o momento para a atividade digital, mas também há o momento de ir para a rua. Por mais incendiárias que sejam as mensagens, a troca de informações, é muito diferente queimar pneu na rede e queimar pneu na rua. 
Ao se constatar que as redes virtuais “[...] se multiplicaram e mudaram o funcionamento das organizações piramidais" ainda se “[...] está longe de fazê-las desaparecer", dado que "a criação das redes virtuais não elimina a materialidade do mundo [...]". Assim, ainda que “[...] a internet desterritorializa no sentido de permitir intercâmbios em escala global, os espaços territoriais continuam a ser tão importantes, ou mais do que nunca [...]". (SORJ, 2003, 55-56) Nesse contexto, as comunidades virtuais devem ser vistas como agregadas sociais que surgem no âmbito da internet quando uma quantidade suficiente de pessoas leva adiante essas discussões públicas durante um tempo suficiente, com suficientes sentimentos humanos para formar redes de relações pessoais no espaço cibernético. (RHEINGOLD, 1996) Para Castells (1999, p. 385) a comunidade virtual, é uma rede eletrônica de comunicação interativa autodefinida, organizada em torno de um interesse ou finalidade compartilhados, embora algumas vezes a própria comunicação se transforme no objetivo. Mamede-Neves e outros (2005) detectam a existência de um afogamento caótico em dados e de um fogo cruzado das imagens, cujo caos atinge a toda a sociedade, fazendo com que, muitas vezes, os adultos pensem em recuar, posição da qual a juventude, pela sua própria constituição, parece não ter medo. Todas essas reflexões nos levam a pensar que as gerações mais jovens, os nativos digitais, podem estar entendendo que tudo acontece nas redes, ou grande parte nas redes. Assim, a política também seria feita e decidida nas redes. Não é de se estranhar a predominância de muitos cartazes dizendo algo como: "[...] saímos da rede, estamos na rua”, ou mesmo convocações do tipo: "sai do sofá, vem pras ruas”.

\section{Redes Sociais, ruas e o junho/13}

Um primeiro ponto a salientar é que esses movimentos pegaram os analistas políticos de surpresa, havendo várias demonstrações da dificuldade de entender teoricamente o que estava acontecendo dado o ineditismo dos movimentos, principalmente quando teóricos tentavam exarar algum entendimento sobre os movimentos no calor dos acontecimentos. E à medida que os movimentos iam tendo seu rumo 
alterado, maiores dificuldades de compreensão teórica emergiam. Isso em grande parte se dava devido à pluralidade dos atores envolvidos e da posição absolutamente diferenciada e desconhecida dos padrões tradicionais, assumida pelo MPL. Como mencionado acima, podemos agrupar os escritos sobre os movimentos em dois grandes blocos, aqueles produzidos no calor dos acontecimentos ou pouco tempo depois e os produzidos alguns meses depois, quando o movimento já havia refluído (ou mudado de característica) e havia já algum, ainda que pequeno, distanciamento temporal.

Castells, que acompanha a realidade brasileira há algum tempo, se manifesta no mês seguinte aos acontecimentos (julho/13), quando na verdade ainda estavam em marcha, não escrevendo mais do que quatro páginas sobre os eventos em um posfácio de um livro sobre a chamada primavera árabe, os chamados indignados bem como os movimentos occupy. Castells capta alguns elementos essenciais de todo esse processo. Começa afirmando que "Aconteceu também no Brasil. Sem que ninguém esperasse". Ainda acrescenta ao seu lote de surpresas: "Sem líderes. Sem partidos nem sindicatos em sua organização. Sem apoio da mídia. Espontaneamente”. A maior parte desse diagnóstico é praticamente concordância geral, mas o "espontaneamente" não reconhece todos os esforços e tentativas feitas pelo MPL em momentos pretéritos. Ainda nota que os direitos humanos não estão sendo respeitados e isto ocorre fundamentalmente devido à uma classe política que estaria agindo basicamente na defesa de seus interesses. Generaliza dizendo que é um processo mundial, pois "[...] a democracia tem sido sequestrada por profissionais da política" que emitem a mensagem que "[...] a política é coisa dos políticos, não dos cidadãos”. (CASTELLS, 2013, p. 182)

O autor ainda associa os movimentos, como de fato ocorreu, à realização da Copa do Mundo de futebol que “[...] converteu-se num negócio mafioso de corrupção em grande escala” envolvendo setores privados e públicos, "[...] utilizando em boa medida fundos públicos sem controle de contas". O autor ainda busca a explicação para os movimentos no modelo de desenvolvimento do País, fazendo críticas à política de educação, saúde, ambiente, expressando que os movimentos se formaram 
de "forma confusa, raivosa e otimista", gerando uma "consciência de milhares de pessoas" que se conectavam tanto nas redes como nas ruas. Por outro lado, "[...] o mais significativo do movimento brasileiro até o momento tem sido a resposta das instituições políticas”, observando que "[...] a classe política em sua grande maioria rechaçou o movimento como demagógico e irresponsável”, sublinhando a violência como os governos de São Paulo, "tucano", e do DF, petista, reprimiram os movimentos. Em sua percepção, foi a primeira vez que a mais alta autoridade do país, a presidente, declarou que “[...] tinha a obrigação de escutar a voz das ruas" legitimando os movimentos e fazendo com que as autoridades locais anulassem os aumentos das tarifas de transporte. Realça também que a presidente “[...] prometeu uma série de medidas (até o momento, apenas promessas), relativas a um grande investimento público em educação, saúde e transporte". (CASTELLS, 2013, p. 183-184)

Aqui reside o problema, a dificuldade de análises feitas enquanto a História está sendo escrita, sem qualquer desfecho mais concreto passível de visualização, ainda que o autor diga que são apenas promessas. Ainda percebe o autor como "mais relevante" a reforma política que possa combater a corrupção e a criação de "[...] um sistema eleitoral mais representativo e fórmulas de participação cidadã que limitem a partidocracia”. Passado um ano e meio dos acontecimentos, pode-se constatar que a resposta veio apenas na forma da suspensão dos aumentos caindo as promessas no vazio, salvando-se apenas, e de forma muito criticada e passível de conflitos, o programa "mais médicos" na área de saúde. A visão favorável de Castells à presidente é estampada quando visualiza uma "[...] profunda inquietude da classe política ante a possibilidade de aliança entre um movimento social autônomo e uma Presidência democrática e democratizante”. Novamente, essa expectativa não se confirmou possivelmente porque as premissas para sua ocorrência sejam falsas. Mas o autor também toma suas cautelas ao entender que "[...] o movimento tampouco confia na presidenta" e assim, “[...] o resultado dessa inovadora interação entre a política nas ruas e a política nas instituições é, no momento em que escrevo este 
texto, julho de 2013, uma questão em aberto", abrindo o autor a possibilidade de que "[...] novamente se aborte a vontade de mudança das instituições políticas” (CASTELLS, 2013, p. 185), o que afinal aconteceu, mais uma vez.

O livro Cidades Rebeldes pode ser considerado um empreendimento ousado, pois lançado no mês seguinte aos eventos de junho/13! Os artigos que tratam do Brasil remetem, em geral, a um engajamento substanciado em quadros mais estruturais para entender o fenômeno, tais como o capitalismo, a acumulação, o papel das cidades, a exclusão. Para a encarregada de fazer a Apresentação do livro, as manifestações podem ser pensadas como "um terremoto" que veio a perturbar "[...] a ordem de um país que parece viver uma espécie de vertigem benfazeja de prosperidade e paz”. Esses movimentos fizeram “[...]emergir não uma, mas uma infinidade de agendas mal resolvidas, contradições e paradoxos. Mas, sobretudo - e isso é o mais importante -, fez renascer entre nós a utopia”. Ao encerrar a apresentação dos artigos, a autora assevera que “[...] a voz das ruas não é uníssona. Trata-se de um concerto dissonante, múltiplo, com elementos progressistas e de liberdade, mas também de conservadorismo e brutalidade, aliás, presente na própria sociedade brasileira”. (ROLNIK, 2013, p. 8, 12)

No mesmo livro, Maricato e colaboradores (2013, p. 19, 26), por sua vez, diz que quem acompanha a realidade das cidades brasileiras “[...] não estranhou as manifestações que impactaram o país”, pontuando, no entanto, que o fato dos manifestantes serem formados por jovens predominantemente de classe média “[...] exija uma explicação um pouco mais elaborada”, o que efetivamente não é feito. Em seu entender, "[...] é impossível dissociar as principais razões, objetivas e subjetivas desses protestos, da condição dessas cidades”. Em seguida, a autora discorre sobre as condições de exclusão das cidades e a deterioração das condições de vida, principalmente dos setores populares, encaixando essa discussão nos parâmetros da hegemonia neoliberal. Finaliza clamando pela reforma política como “[...] primeiro item necessário à política urbana”. 
No mesmo pacote, Carlos Vainer $(2013$, p. 36, 39) identifica que todos "[...] foram pegos de surpresa pelas manifestações de massa que mudaram a face e o cotidiano de nossas cidades em junho". Argumenta que os movimentos dominantes nas quase duas décadas anteriores eram movimentos sociais rurais, enquanto as lutas urbanas mostravam muita fragmentação e dispersão e que havia muita dificuldade de unificação dessas lutas. Mao dizia que uma fagulha pode incendiar uma pradaria, pois esta "[...] ]estava seca, pronta para incendiar-se" sendo, agora, a pradaria as nossas cidades. Para o autor, existe uma "conexão estreita entre os protestos em curso" e os "maciços investimentos" ligados à Copa de 2014 e aos Jogos Olímpicos de 2016. Vendo a questão de ponto de vista mais estrutural, associam-se a cidade e o planejamento no contexto da valorização do capital e da lógica neoliberal, na qual predomina o mercado, o que se expressa no fato de remoções forçadas para a periferia deixando a cidade livre para os mega eventos, "[...] periferias distantes, a duas, três ou quatro horas dos locais de trabalho, a custos monetários absurdos e condições de transporte precaríssimas", como também se verá na análise da RV. Assim, dado esse "[...] contexto, o surpreendente não é a explosão, mas que ela tenha tardado tanto".

Iasi (2013, p. 41-44) também vai assentar sua compreensão do fenômeno em fundações mais estruturais sobre a sociedade contemporânea, o capitalismo recorrendo à Freud, Sartre, Luckács e outros para fundamentar sua análise. Assim, as contradições urbanas são vividas pelas pessoas na “[...] forma de uma serialidade, isto é, presas em seus casulos individuais", não formando um grupo e sim “[...] um coletivo serial no qual prevalece a indiferença mútua”. A sociabilidade criada historicamente na sociedade burguesa se apresenta como "[...] realidade à qual temos de nos submeter, reprimindo nossos impulsos". Trazendo esse sintético, mas denso, referencial para o fenômeno em tela, ao perceber que houve aumento da passagem do ônibus, "[...] o indivíduo serializado pode reagir de duas formas: aceitar, porque “a vida é assim, fazer o quê?" ou reclamar, pois “[...] a vida não deveria ser assim - e pagar”. Em outras palavras, “[...] os indivíduos vivem a revolta ou buscam a adaptação no interior da serialidade”. O papel da ideologia, 
nesta construção é central, pois "Adaptado ou revoltado, o indivíduo serializado segue sua vida subsumido ao real. A ideologia é a forma da subjetividade que permite dar sentido a essa subordinação".

Além da ideologia, outra mediação é a luta, que é "mais complexa", se corporificando nos movimentos sociais, nos sindicatos, partidos de esquerda, havendo a sensação de que “[...] são sempre uma minoria os que lutam”. A essa altura, o autor chama a atenção para o fato de que, ao contrário do que alguns pensam, “[...] o problema não é somente uma questão de organização e comunicação", identificando a existência de um "[...] atual culto fetichizado dos meios", que explicaria a "[...] explosão de insatisfação popular ocorrida Brasil afora em junho de 2013 que teria sido determinada pelo uso de novos meios convocativos, com as redes sociais na internet”. (IASI, 2013, p. 44) Este presente artigo subscreve completamente esta visão, colocar a tecnologia em primeiro plano é colocar o carro na frente dos bois, é confundir meios com fins, conforme já apontou Pinho (2008). Iasi (2013, p. 44-46), evidentemente, não diminui a importância dos meios e das formas de comunicação, mas alerta que “[...] o problema é de outra natureza” constituindo-se "[...] um diálogo entre dois segmentos da classe trabalhadora que estão em momentos diferentes do processo de consciência”. Assim, quando os jovens do MPL “vão para as ruas" e tanto o Prefeito de São Paulo quanto o Governador de São Paulo recusam o corte do aumento das passagens e este último mobiliza as forças da Polícia, era de se esperar uma "volta à normalidade" havendo uma "[...] confiança na passividade imposta aos movimentos sociais” por parte do governo federal. Porém, “[...] a repressão aos jovens e à prepotência dos governantes funcionaram como catalisador das contradições que germinavam sob a aparência de que tudo corria bem em nosso país". Assim, "[...] o dique da ideologia não foi capaz de contê-la" [a vida que transbordava]. O autor ainda registra que os "[...] patéticos pactos propostos pela presidente Dilma” correspondiam a uma estratégia de que "tudo deve continuar como estava".

Ao examinar como é que os movimentos mudaram de escala quantitativa, Peschanski (2013, p. 59) faz uma importante diferenciação 
para entender os movimentos de junho/13, qual seja, esses protestos não começaram "[...] "contra” algo, mas como uma expressão coletiva "a favor" de algo", no caso a recusa encabeçada pelo MPL ao aumento de 20 centavos na passagem. Para Secco (2013, p. 72, 74, grifo do autor) as jornadas de junho pareciam "um enigma". Ao constatar o aumento brutal de manifestantes nas ruas, entende-se que, a princípio, havia “[...] a pauta popular, organizada de baixo pra cima" trazendo a questão da tarifa do transporte, ao que se somou, em seguida, uma "pauta de massa" vinda de cima para baixo, onde ocorre uma crítica aos políticos consubstanciada em um emaranhado de demandas. Secco também traz a questão das formas de comunicação para a compreensão dos movimentos. Afirma que, apesar de "[...] a maioria dos jovens manifestantes usar a internet para combinar os protestos, os temas continuam sendo produzidos pelos monopólios de comunicação". Assim, "A internet é também um espaço de interação entre indivíduos, mediada pelo mercado de consumo e vigiada pela 'inteligência dos governos'". [ênfase no original] Esta interdependência entre internet e imprensa (ou mídia em geral) ficará concreta ao se examinar o movimento Fora Sarney, adiante. Secco aponta ainda uma guinada no movimento quando, a partir do momento que a violência passou a fazer parte das manifestações, ocorreu uma “[...] queda abrupta do número de manifestantes", o que o leva a atribuir que o movimento que tinha no seu início um caráter "[...] apartidário se tornava, então, antipartidário".

Venício de Lima (2013, p. 90) também toca na questão do uso das redes para a mobilização. Sendo a maior parte dos participantes formada por jovens e estando "conectados" pelas redes e não estando representados e nem encontrando expressão através da "velha mídia", esses jovens "ainda dependem dela para alcançar visibilidade pública, isto é, para serem incluídos no espaço formador da opinião pública”. Isto se deve ao fato de que a mídia, principalmente a televisão, "[ainda] controla e detém o monopólio de “tornar as coisas públicas'”. Além de dar visibilidade, ela é indispensável para 'realimentar' o processo e permitir sua própria continuidade”, o que também será visualizado no FS. 
Uma tendência para a construção de um entendimento teórico se apoiou na citação dos movimentos anteriores mais significativos da sociedade brasileira, o Diretas-Já e o movimento dos "caras pintadas", mas ressalvando-se que eram momentos, situações e movimentos, muito diferentes dos protestos de 2013. Neste caso, emerge uma clareza que se estava frente a um novo animal político. De qualquer forma, é bom aprender algo mais estrutural com, pelo menos, os "caras pintadas" por ter em comum com o movimento mais recente o fato de ter tido uma predominância de juventude. Escrevendo anos antes das recentes manifestações de rua, José de Souza Martins (2011, p. 95, 96, 98) lembra que, no processo que pleiteava o impeachment de Collor, “[...] a população só tardiamente foi às ruas e, mesmo assim, quem o foi era notoriamente uma bem definida categoria de jovens estudantes, os chamados 'caras pintadas'”. O autor mostra que a tradição brasileira assenta-se no mecanismo da troca de favor. A relutância da população em ir às ruas para apoiar as investigações parlamentares contra Collor explica-se pelo fato de que a população “[...] não podia ver ilegalidade no que lhe era, aparentemente, legítimo. Legitimado, além do mais, pela tradição da política de troca de favores". Assim, o ir para a rua pode ser visto mais como exceção do que como regra na realidade brasileira. As manifestações de rua foram fundamentais para aprofundar as investigações, produzindo “[...] uma nova realidade política baseada numa espécie de dupla e contraditória legitimidade: a legitimidade do voto e a legitimidade da rua". É possível também identificar uma forte contradição pois, no caso da cidade da cidade de São Paulo, a população que foi às ruas pedir a cassação de Collor, ou a que não foi impedir a cassação do presidente, na eleição seguinte “[...] elegeu um político submetido a reiteradas acusações de corrupção”. Não há como negar essa afirmação, mas esta deve ser levada como uma figura de retórica, pois seria preciso identificar quem foi às ruas pedir a cassação do presidente e quem votou no suspeito candidato a prefeito, pois não são o mesmo grupo. Os que vão às ruas, no caso do pedido de impeachment de Collor podem ser vistos como uma "[...] espécie de multidão iluminista, que vislumbra o conflito entre a impessoalidade do poder e o uso 
pessoal do poder, condenando este último". Acreditamos que este diagnóstico, entendimento da questão, pode, em grande parte, ser aplicado às manifestações de 2013 .

Recorrendo ainda a Souza Martins (2013), passados seis meses do encerramento das manifestações, o autor faz uma pertinente diferenciação entre movimentos sociais e manifestações coletivas. Embora não os conceitue, parece possível inferir como movimentos sociais os movimentos tradicionais, enquanto que manifestações coletivas são aquelas que "[...] dão voz e visibilidade à maioria silenciosa". Complementa o autor que, no regime militar, emergiu um sujeito político com "[...] demandas tópicas que incluíam reformas sociais", enquanto que no "decênio do petismo" germina, em silêncio, um outro sujeito político, de caráter "claramente antipartidário" que reflete o "descrédito da política”. Ao identificar que sendo manifestações de classe média, a educação já não entra na pauta (ver abaixo), “[...] mas se motiva na educação para o protesto”. O autor faz uma importante diferenciação observável nos protestos, “[...] o protagonismo do manifestante contra o do militante”. É oportuno lembrar que houve uma recusa à participação de partidos com suas bandeiras, indicando não só recusa por parte dos manifestantes das estruturas partidárias como também a percepção da captura instrumental dos movimentos por parte dos partidos políticos, coisa que os manifestantes queriam evitar.

Michael Löwy (2013), que também tem sido um importante observador da cena política brasileira, em pronunciamento ao final de 2013, portanto já um tanto distante do calor dos acontecimentos, registra que, por morar em Paris, não acompanhou as “[...] jornadas de junho in loco”. Em sua primeira vinda pós-manifestações iniciais, sentiu ainda "uma agitação no ar" que eram novos capítulos "desse longo junho". Para ele, os 20 centavos foram "a faísca” e, como "a pólvora estava seca”, aconteceu que "[...] as chamas se alastraram rapidamente". Interessante notar que o autor observa que "[...] o movimento explodiu quando as pessoas deixaram de ficar só no Twitter e no Facebook, saíram do sofá e foram à rua, essa coisa antiga”. Aqui cabe um parêntesis. Como este artigo persegue também o objetivo de confrontar experiên- 
cias nas quais essas tecnologias digitais não existiam e as atuais com a disponibilidade de uso intenso dessas tecnologias, então cabe perguntar onde ficavam antes as pessoas que tinham um engajamento político já que não existiam essas tecnologias. Pode parecer uma questão prosaica, mas, na forma colocada, parece que existem dois momentos de mobilização política: no sofá, no Twitter e no "Face" e, depois, na rua. Obviamente, antes da internet, as pessoas se mobilizavam, discutiam, debatiam e iam para as ruas.

Voltando à Löwy (2013), a ida às ruas provocou um "terremoto" que não era só pelos 20 centavos, isto, apenas simbolizava "[...] um sentimento profundo de injustiça social, de insatisfação com os rumos administrativos das cidades, de indignação com a ordem das coisas no mundo". Em seu entender, a luta pelo passe livre mexe em questões estruturais que "[...] o transporte público deve ser público e gratuito, isto é, não deve ser um negócio". Assim, a luta pelo transporte gratuito carrega uma proposta de que outra realidade é possível, em seu olhar. Observa ainda o autor que "[...] à repressão brutal da polícia” em São Paulo e Rio, aos estudantes juntaram-se outros setores da sociedade que também "foram às ruas". O autor ainda registra que outras questões começaram a "pipocar", "[...] muito justas, mas diversas: o dinheiro esbanjado nos estádios da Copa, a precariedade nos campos de saúde e da educação, os políticos corruptos, e assim por diante". Sintetiza assim o autor suas observações que as jornadas produziram “[...] duas ideias emancipadoras. Primeiro, a importância do serviço público para a sociedade. Segundo, se quiser seus direitos, o povo precisa ir às ruas". Detendo-nos neste último, parece ser possível extrair que Twitter e Face não fazem a revolução, ao que tudo indica o teatro de operações ainda é a rua, o locus concreto e não virtual.

Marco Aurélio Nogueira (2013, p. 19-20) se manifesta na introdução de um livro seu sobre os movimentos em setembro de 2013, ou seja, bem pouco tempo depois dos protestos de junho e seus desdobramentos. Em seu entender, as razões da "efervescência" das massas estão inscritas "[...] na realidade do capitalismo globalizado, na história nacional e na conjuntura política”. Os protestos se voltaram 
contra "[...] as deficiências do sistema de prestação de serviços públicos”. A briga não se deu pelos vinte centavos, “[...] mas por muito mais, talvez por quase tudo". A luta foi estruturada ignorando "[...] parlamentares, sindicatos e partidos políticos" ocorrendo de "modo espontâneo e improvisado", dirigia-se com clareza "[...] contra o governo representativo tal qual estruturado no Brasil” se voltando contra "[...] todos os governos: contra o sistema político, seus atores, seus procedimentos e sua cultura”. Os protestos questionaram o sistema que se expressa “[...] na conduta dos políticos, dos partidos e dos governantes", que leva ao "[...] enriquecimento de certos atores e à disseminação de ilícitos de todo tipo".

A crise que se apresenta "[...] é mais que crise política: é crise de um sistema perverso", crise esta que "não surgiu de repente", mas foi se aprofundando tanto no plano federal como nos Estados (para não mencionar os municípios) que são marcados por “[...] falhas graves e desempenho medíocre” onde a corrupção "cresceu ininterruptamente". Esse sistema aprofundou o fosso entre "[...] a miséria de boa parte da população e os gastos desnecessários, o desperdício e o uso suntuoso de recursos públicos pela elite política e administrativa" dos três poderes. (NOGUEIRA, 2013, p. 21)

No entender de Nogueira (2013, p. 22-23), essa "perversão sistêmica” acentuou-se durante o período em que o PT assume o poder federal. Lembra o autor que este partido marcou a história política brasileira "em sentido positivo" ajudando a mudar "a face social do país", fazendo a inclusão social. Porém, enquanto "ator político" acabou se comprometendo, "sujou as mãos", acabou organizando "[...] coalizões à direita e a operar o velho jogo político que antes condenava” bem como se distanciou da sociedade civil. Ainda que tenha encertado políticas de combate à miséria, "[...] combinaram assistencialismo paternalista e direitos de cidadania”, o que veio a produzir "[...] efeitos sociais importantes, mas que não modificou a estrutura do país”. Nos passos de Gramsci, ao invés de construir um "[...] projeto de hegemonia, organizaram um projeto de poder”. Como os governos petistas reproduziram "[...] as bases do clientelismo, do patrimonialismo e da 
corrupção" este fato atuou como "combustível adicional de frustração e indignação" que acabou por aumentar com a percepção dos “[...] gastos exorbitantes e sem critérios claros, o enriquecimento dos dirigentes políticos”, entre outros aspectos.

Como os partidos políticos “[...] pesam pouco na organização de consensos sociais”, Nogueira (2013, p. 23) percebe que tem “[...] uma revolução em marcha, mas ela não é nem a dos trabalhadores e nem a das classes médias". Entende tratar-se de “[...] uma revolução sem revolução, a sociedade ultrapassando o sistema político e pondo em xeque o que está instituído". O que o autor constrói pode parecer um paradoxo, mas como vários autores pontuaram que era de difícil compreensão o que havia acontecido, parece que um paradoxo, ou um aparente paradoxo pode servir para entender os acontecimentos. É essa também a posição do autor em tela ao afirmar que tudo emergiu “[...] de uma só vez. Daí, talvez, a dificuldade para que se compreenda o que se passou. É que o país ficara diferente e não se havia dado conta disso".

Ainda outro ponto merece destaque na formulação do autor quando aponta que os eventos ocorreram com "[...] tendências 'niilistas' pré-políticas”, advertindo não fazer sentido "romantizar os protestos, vê-los como sendo o anúncio de uma democracia revitalizada e ignorar que eles foram uma 'terra de ninguém', aberta ao protagonismo genérico de muitos grupos e indivíduos". Refreia ainda os espíritos mais otimistas ao afirmar que "As ruas brasileiras têm baixo poder de agenda”, mas “[...] seu efeito positivo não pode ser desprezado. A vida política não será mais a mesma, ainda que demore para mudar”. (NOGUEIRA, 2013, p. 24) O autor põe, assim, o freio naqueles que esperavam mudanças repentinas e automáticas, falando até em revolução.

André Singer (2013, p. 23, grifo do autor), por sua vez, entende que em junho/13 houve "um tremor de terra", mas longe de "um terremoto", dado que "[...] relações de classe e propriedade não estiveram diretamente no centro das manifestações". Evidentemente, isto não fazia parte do menu, e dificilmente tem pertinência na realidade das reações da sociedade brasileira. Mesmo escrevendo alguns (poucos) 
meses depois do evento estabelece que "[...] nunca restou nítido o que estava acontecendo".

Singer (2013, p. 23-24) enfatiza que não dá para imaginar, "seriamente", estar acontecendo “[...] uma tentativa de revolução”. Parece que se valoriza muito a ideia de que qualquer movimentação da sociedade seja uma revolução. Os eventos cumpriram três fases: na primeira, uma “[...] fração pequena, embora valorosa, da classe média” realizou as mobilizações em São Paulo com objetivo da redução das passagens do transporte público. As manifestações foram engrossando o número de manifestantes até que a violência policial se manifestou. Na segunda etapa dos movimentos, houve uma incorporação de maior número de manifestantes quando "[...] outras frações da sociedade entram espontaneamente em cena", ao mesmo tempo em que ficam "vagas as suas demandas". As demandas são embasadas em críticas à falta de educação, saúde, moradia e contra os gastos com a Copa das Confederações, contra a corrupção, bem como à classe política e aos partidos, registra Singer.

Quando a Copa das Confederações começa, São Paulo “[...] perde centralidade, com o protagonismo passando as praças onde haveria jogos", sendo que no Rio, as manifestações “[...] adquirem certo sabor de sublevação popular". Na terceira etapa, que vai do dia 21 de junho até o final do mês, “[...] o movimento se fragmenta em mobilizações parciais com objetivos específicos" (SINGER, 2013, p. 24, 26) e pontuais. Refletindo sobre os acontecimentos, Singer (2013. p. 27-28) observa que o tema "[...] deverá ser alvo ainda de muita pesquisa" e assim estabelece algumas hipóteses, construídas "quase no calor da hora", detendo-se em dois aspectos: "[...] a composição social e as ideologias que se cruzaram nas ruas". Quanto ao primeiro aspecto, defende que a composição social continha tanto uma "classe média tradicional" junto ao "novo proletariado", formado por trabalhadores jovens com carteira assinada, mas em situação de "[...] baixa remuneração, alta rotatividade e más condições de trabalho”. A composição era predominantemente de jovens somados a jovens adultos e também com alta escolaridade. Os dados também mostram que se detectava nas ruas “[...] uma míni- 
ma parcela de baixa escolaridade, denotando a virtual ausência da base da pirâmide social brasileira nas manifestações".

Mais que isso, os dados revelam uma grande participação de universitários, atingindo, no caso de São Paulo, quase 80\% do contingente dos manifestantes. Quando se acrescenta os estudantes de nível médio, as manifestações teriam assumido "[...] fortes tintas de classe média tradicional”. Porém, ao se inserir os dados de renda, verificase que metade dos manifestantes estavam no grupo de baixa renda (menos que 5 salários mínimos), indicando que cerca de metade dos manifestantes pertenciam à “[...] metade de baixo da estratificação por ocupações" revelando que "[...] o novo proletariado ou precariado, conforme sugerido por alguns autores, foi para as ruas”. (SINGER, 2013, p. 29, 31)

Ao se fundamentar em todos os dados de pesquisa disponíveis, Singer sugere que "a melhor imagem" para retratar a composição social dos manifestantes, seja a de "[...] dois blocos relativamente equivalentes, formados por jovens e jovens adultos de classe média e outro por pessoas da mesma faixa etária, mas pertencentes à metade inferior da estrutura social brasileira, sendo estes com menos escolaridade média”. (SINGER, 2013, p. 31)

É oportuno notar que a palavra é usada no plural, manifestações, foram várias. E entendemos que à medida que as novas manifestações iam ocorrendo ia também atraindo outros segmentos sociais. Como as pesquisas não aconteceram nas primeiras manifestações, até porque não se sabia o vulto que iam tomar, fica-se mais com aquelas acontecidas após as primeiras rodadas. Mas, é certo, que tendo sido as manifestações convocadas pelo MPL, a composição inicial seria fundamentalmente de jovens e estudantes. Ao se engrossar a fileira dos manifestantes nas rodadas subsequentes, Singer (2013, p. 34) defende que "[...] o que havia sido um movimento da nova esquerda passou a ser um arco-íris, em que ficaram juntos desde a extrema-esquerda até a extrema-direita", predominando cartazes contra a corrupção e a cobrança de impostos e, ainda, críticas aos gastos com a Copa de 2014 e as Olimpíadas de 2016. 
Em suma, Singer (2013, p. 36) entende que, talvez, de uma maneira um tanto simplificada ou reducionista, "[...] a direita trouxe para a segunda fase das manifestações o problema da corrupção e a esquerda, o das iníquas condições da vida urbana”, mas registrando que “[...] o realmente novo foi a atuação do centro, o qual teve a vantagem de poder assumir uma e outra bandeira, bradando simultaneamente contra os gastos públicos privatizados pelo capital e contra a corrupção”.

Vale ainda trazer o registro feito por André Singer (2013, p. 33) sobre o perfil do MPL, quando de uma entrevista dada ao Programa Roda Viva da TV Cultura-SP por dois representantes do MPL apenas expressaram o “[...] que se poderia chamar de 'mandato imperativo': só disseram o que a 'assembleia' os autorizava a dizer”, recusando-se a falar de suas vidas pessoais, “[...] abstendo-se de aproveitar a oportunidade para projetar-se como liderança individual, pronta para ser absorvida e tragada pelo star system", ou seja, afastaram-se da política tradicional de exploração do papel das lideranças.

Uma das contribuições de Maria da Glória Gohn (2013) se dá cerca de um mês depois dos eventos entendidos como expressando "[...] estados de indignação face à conjuntura política nacional”. A autora formula a questão fundamental: “[...] porque uma grande massa da população aderiu aos protestos"? Em seu entender, os "prováveis motivos", indo além da questão da tarifa, estão localizados, nos “[...] gastos altíssimos com estádios da Copa, megaeventos e uso do dinheiro público em eventos promocionais, a má qualidade dos serviços públicos, especialmente transportes, educação e saúde" e, ainda, entre outros, "inflação, denúncias de corrupção" ao lado de "[...] sentimento de impunidade, sistema político arcaico, criminalização dos movimentos sociais" e ainda outros. Assim, a ideia de um “[...] Brasil tudo azul, para o senso comum de seu povo em geral, era uma construção irreal”. Observa ainda a autora que com a violência empregada pela Política, “[...] este 'povo' saiu às ruas e mais uma vez demonstrou que a cordialidade do brasileiro tem limites".

Buscando caracterizar os movimentos, os vê como "[...] uma nova forma de movimento social composta predominantemente por jovens, 
escolarizados, predominância de camadas médias, conectados por e em redes digitais, organizados horizontalmente e de forma autônoma". Essas características fazem com que se tornem "[...] críticos das formas tradicionais da política”, “[...] especialmente os partidos e os sindicatos". O movimento, convocado pelas redes sociais, "[...] acontece 'em se fazendo' e não via grandes planos de organizações com coordenações verticalizadas", tornando-se “[...] laboratórios de experimentações de novas formas de operar a política”. (GOHN, 2013)

Em termos da formação dos manifestantes, entende a autora que “[...] poucos têm trajetórias de militância e experiências associativas anteriores. Participam de coletivos, mas preservam valores individualizantes, que é diferente de individualista". Também localiza nestes “[...] uma profunda falta de confiança em toda forma de política e categoria de políticos", desejando "[...] outro país onde a ética e política andem juntas". Como não se sentem representados pelo sistema político existente, “[...] detecta-se também uma crise de representação social desses grupos e uma crise de legitimidade das instituições públicas”. (GOHN, 2013)

Do ponto de vista da ideologia que move esses manifestantes, Gohn (2013) entende que "[...] não há hegemonia de apenas uma ideologia”, sendo as fontes a esquerda, o anarquismo e o socialismo libertário, a autogestão, como também “[...] um novo humanismo na ação de alguns, expresso em visões holísticas e comunitárias, que critica a sociedade de consumo, o egoísmo, a violência cotidiana".

A autora ainda identifica que uma das questões "profundas" que está na agenda dessas manifestações se refere à "discussão da democracia”, elaborando que enquanto a “[...] democracia representativa está em crise" e a democracia direta é viável apenas em pequenos grupos, emerge a democracia deliberativa, mas que onde tem ocorrido "[...] padece de arranjos clientelísticos". Assim, em seu entender, as manifestações expressam a busca por "[...] novas formas de organização política, nos marcos da democracia”, mas que ainda não está clara. A autora ainda relembra que "[...] a luta pelos transportes públicos é histórica" (GOHN, 2013) relembrando a Revolta do Vintém em 1880 no Rio de 
Janeiro, a ser considerada na sequencia deste artigo, bem como lutas pelo transporte no final dos anos 1970 em várias cidades brasileiras.

Fazendo uma síntese apertada dessas contribuições teóricas, talvez possa se identificar dois grupos bem definidos. O primeiro situa as manifestações em críticas ao capitalismo, ao neoliberalismo, à ordem mundial hegemônica, ainda que, vez ou outra, salpicando com alguns elementos da conjuntura do País. O segundo grupo, ainda que também faça referências a um quadro mais geral, e até internacional, situa a origem e motivação das manifestações mais em problemas da estrutura do País, da trajetória histórica do Brasil, e com ênfase na conjuntura, principalmente a gerada a partir dos governos do PT no plano federal com opções de política e de políticas públicas feitas pelos ocupantes do poder federal.

\section{OS PROTESTOS DE JUNHO/13}

Muito do que foram as manifestações já foi apresentado acima, mas, acredita-se, que um passo necessário para entender estas manifestações coletivas demanda caracterizar seus participantes. Para tanto, recorremos à Pesquisa IBOPE realizada em 20 de junho de 2013 em oito capitais com 2002 entrevistados, que encontrou os seguintes resultados pesquisa realizada quando os movimentos já tinham sido encorpados, ou seja, não capta as primeiras manifestações:

- Idade: 14 a 24 anos: $43 \%$.

- Escolaridade: Superior: 43\%; até o colegial incompleto: $8 \%$

- Trabalha: sim,: 76\%; Estuda atualmente: $52 \%$.

- Renda familiar: até 2 Salários Mínimos (SM): 15\%; Mais de 5 SM: $49 \%$

Essa bateria de dados permite observar que as manifestações contaram fundamentalmente com um público jovem, com formação educacional elevada, formada em grande parte por estudantes, mas também trabalhadores. E o perfil de renda para os padrões brasileiros é relativamente alto. 
- Razões para participar: transporte público: 37,6\%; ambiente político: 29,9\%; saúde: 12,1\%; contra a PEC37: 5,5\%; educação: $5,3 \%$, Gastos com as copas: $4,5 \%$, Luta contra o capitalismo: 0,1\%; Aumento de salários: 0,2\%

Essa bateria de dados, por sua vez, mostra que a motivação básica para participar reside na questão do aumento da passagem do transporte público. Mas não é nada desprezível que a insatisfação com o ambiente político venha logo em segundo lugar. Ao se somar essas duas queixas, atinge-se um total de $67,5 \%$, o que mostra que ao lado de uma motivação bem focada alinha-se uma de caráter mais difuso com o quadro político do País. Nota-se também que a insatisfação com serviços públicos consubstanciados em Saúde e Educação, responsabilidade do Estado, atinge 17,4\%. Ainda vale mencionar a presença no pacote de insatisfações os gastos com a Copa e uma menção a PEC 37. Cabe, ainda, notar que as demais são irrelevantes do ponto de vista quantitativo, mas eram normalmente ponto de agenda obrigatório dos movimentos mais tradicionais, expresso pela luta por salários e contra o capitalismo. Tudo isso leva a confirmar que se estava frente a um novo tipo de movimento bem como de participantes, como já registrado várias vezes.

- Participações anteriores: já: 54\%; $1^{\mathrm{a}}$ vez: $46 \%$

- Como soube: face 62\%; internet $29 \%$; amigos e colegas $28 \%$; TV $14 \%$; jornais $4 \%$, rádio $4 \%$, base do movimento: $3 \%$

Essa bateria de dados mostra que uma parte significativa dos manifestantes, praticamente a metade, era neófito em termos de participação em eventos deste tipo. Por outro lado, a forma de conhecimento da realização das manifestações, predominando o Facebook e a internet, convergem com o dado da participação predominante de jovens.

- Se sente representado por algum político: Não 83\%; por algum partido: Não $89 \%$.

Esse dado mostra claramente o que já foi revelado acima sobre a crítica ao ambiente político, ao expressar que partidos e políticos elei- 
tos não representam majoritariamente os cidadãos, mostrando a falência do sistema político.

Uma conclusão possível a ser extraída é que foi um movimento de jovens, uma boa parte de estudantes, muitos já com nível superior, um movimento fundamentalmente de classe média, mas não só, e de caráter apartidário. Vale reforçar que sendo esta pesquisa realizada no dia 20 de junho, após manifestações anteriores, esta última e as seguintes já devem ter capturado um público que ia além do protesto contra o aumento das passagens.

\section{MOVIMENTO FORA SARNEY}

Nesta seção, vamos examinar o Movimento Fora Sarney (FS), levado a cabo em várias capitais no Brasil ao longo de 2009, detendo-nos no caso de Salvador, escolhido por facilidade de acesso e possibilidade de acompanhamento constante.

Antes de proceder a análise do estudo de caso, vale notar que a expressão \#forasarney foi usada pela primeira vez em 17 de junho de 2009 pelo humorista e apresentador de TV Rafinha Bastos. Sua motivação foi a série de denúncias de irregularidades no Senado brasileiro alavancada pelos atos secretos, sendo um dos maiores beneficiados por eles o presidente da Casa, José Sarney (PMDB-AP). Em 29 de junho, coordenado com um evento contra Sarney na capital de seu estado de origem (São Luís, no Maranhão), o volume de mensagens que continham a hashtag \#forasarney superou a marca de 10 mil mensagens por hora, de modo que a página chegou a ficar fora do ar pelo excesso de mensagens. Em 30 de junho e $1^{\circ}$ de julho, foram marcadas manifestações públicas em várias grandes cidades brasileiras que, apesar do apoio de celebridades e de partidos de esquerda, reuniram poucas pessoas e, em Florianópolis e Porto Alegre, nenhuma. (FORASARNEI, 2009) Os protestos realizados em 01/julho/2009 em São Paulo reuniram 70 pessoas na Avenida Paulista, em Campinas apenas 10 pessoas em frente à prefeitura, no Rio de Janeiro 30 manifestantes se reuniram frente à Câmara Municipal, no Amapá, domicilio eleitoral do senador, um ato convocado por partidos de esquerda. O que se 
pode perceber é que o forte ativismo nas redes não vazou para as ruas que teve um número pífio de participantes nas manifestações, sendo oportuno mencionar que o título da matéria do jornal era exatamente "Protestos organizados por meio do Twitter falham no mundo real", indicando um profundo gap entre a participação nas redes e aquela no mundo real, nas ruas.

Além dessa característica, o movimento não conseguiu deslanchar nas capitais brasileiras, esgotando-se assim que as denúncias contra o senador José Sarney foram arquivadas pelo Senado. Em Salvador, contemplado em profundidade neste artigo, talvez uma das capitais onde o movimento tenha tido uma duração maior, aconteceu o mesmo, ainda que o movimento tenha se mantido na rede por alguns meses mais após o encerramento das manifestações de rua. A esse respeito vale dizer que o episódio que conseguiu maior adesão, o número de participantes chegou, segundo estimativas, a 150, um número certamente baixo para conseguir resultados mais expressivos. O principal jornal da Bahia noticiava em breve nota que Salvador aderia ao "Fora Sarney" quando cerca de 90 estudantes percorreram a Av. Garibaldi em protesto pela renúncia da presidência do Senado, do senador José Sarney (A TARDE, 16/08/2009)

No contexto deste artigo, dois aspectos do movimento despertam interesse para pesquisa: 1) já fez uso de tecnologias de informação, notadamente o Orkut, que tinha uma posição hegemônica naquela época no Brasil; 2) tinha um objetivo, um foco bem claro, o combate à corrupção e um engajamento no sentido de remover o senador José Sarney da política, através da cassação de seu mandato. O FS tinha, como vemos, um objetivo bem ambicioso qual seja, de mover um político tradicional, um oligarca onipresente, com mais de cinco décadas na política brasileira sobre o qual pairavam sérias suspeitas de envolvimento em corrupção. A estruturação do movimento e da luta indicarão que o FS apresentava algumas características similares aos movimentos de 2013, mas também outros aspectos que diferenciavam os dois movimentos. 
Podemos arrolar as seguintes características do FS em sua versão soteropolitana. O FS foi criado em 04 de agosto de 2009, em Salvador, no Orkut, em uma comunidade aberta para não membros. A descrição declarava ser uma "comunidade desenvolvida para expressar a indignação dos baianos ante a situação política atual, especialmente no que tange o senador José Sarney”. (PINHO et al., 2010) Em primeiro lugar, o movimento foi basicamente constituído por jovens estudantes do segundo grau e, ao que tudo indica, de escolas particulares, pertencentes a camadas de classe média e de classe média alta. Chama atenção o fato de, praticamente, não participarem estudantes universitários, o que já incita ao seguinte questionamento. Por um lado, estariam os universitários distanciados da política? Por outro lado, esta nova "geração" de estudantes do segundo grau teria despertado para a política e para uma luta contra a corrupção, e ainda mais sendo estudantes de um extrato social mais elevado? O artigo não dará respostas a todas essas questões, diga-se de antemão, pois não foi feita nenhuma pesquisa direta. Conforme já mencionado nesta introdução, um aspecto diferenciador entre movimentos seria a sua localização geográfica, o lócus onde se deu. Este, pela característica mostrada da inserção social de seus membros, foi, evidentemente, um movimento que aconteceu na região central de Salvador, ou seja, não foi um movimento ocorrido na periferia.

A metodologia de pesquisa ficou assentada no acompanhamento da comunidade do movimento FS no Orkut, já que, conforme dito acima, o movimento usou intensivamente a comunicação digital. Assim, a partir das mensagens dos participantes sobre as estratégias de luta e os conflitos resultantes de posições diferenciadas entre os membros do movimento, Pinho e colaboradores (2010) extraíram os seguintes elementos:

Galera gostaria de saber quem está organizando o movimento? Por exemplo, depois da [Avenida] Garibaldi, existe a intenção de nos deslocarmos para algum lugar? Vamos andar no meio da rua para parar o trânsito? Abraços a todos, espero encontrar todos sábado. (14/08/2009) 
Andar no meio da rua, só funciona com auxilio da polícia ou da reguladora de trânsito. A organização do Movimento FORA Sarney Bahia, em termos de net, está nas mãos do perfil "FORA Sarney Bahia", mas nada monopolizado, pq estamos todos com o mesmo intuito. Basta mandar um e-mail para forasarneybahia@ hotmail.com, ou deixar scrap no perfil (adicionem, quanto mais gente no perfil e a comentar, melhor.) que a galera publica as ideias na comu. Obs.: A comunidade é para compartilharmos nossas ideias a respeito do MOVIMENTO, que não será somente marcado por passeatas, faremos, todos juntos, muito barulho através da net. Já se está preparando algo para logo em seguida da caminhada. Manifestem-se e sugestionem. Grande abraço. (14/08/2009)

Agora a semente foi plantada. Esse foi o começo de uma revolta que não vai mais parar! Nos indignaremos e sairemos nas ruas até que a justiça seja feita no nosso país! Até que, não só o Sarney saia, mas também toda essa bandalheira do senado... todos esses corruptos que ficam aí sugando nosso dinheiro na surdina, que nem um bando de sanguessugas! Chega de sujeira moral, chega de fisiologismo! Fora Sarney e toda a quadrinha do senado! (15/08/2009)

A análise empreendida constatou um baixo índice de debate político em comparação com as postagens que tratavam dos aspectos operacionais das manifestações e do movimento. (PINHO et al., 2010) Os organizadores do site se empenhavam em não acalentar o debate político, tentando manter a unidade do movimento em torno dos propósitos de protesto consensuados pelo grupo sentindo o risco de que se o debate fosse aberto, o movimento se esgarçaria.

Este depoimento recolhido da lista ilustra bem o que está sendo dito:

Cara, eu não quero criar conflito, mas eu não concordo com você e da forma como você coloca suas críticas, apesar de concordar com algumas de suas ideias. Mas acho que você as expõem de forma ofensiva. Eu, apesar de fazer críticas ao movimento, faço parte dele e nunca me oponho ao seu crescimento. (11/09/2009)

Outra constatação foi a elevada concentração de postagens por um pequeno número de autores, dado que apenas $5 \%$ dos participantes 
foram responsáveis por criar $76 \%$ dos tópicos. Esta situação nos leva a questionar a recorrência comum às tecnologias como tábua de salvação para a política. O fato de ter a tecnologia não quer dizer que vai se operar uma mágica em que todos ou muitos participarão, emitirão opinião só porque existe a tecnologia. (PINHO, 2008) Isto posto, percebe-se que mesmo nos casos onde são poucos os que "falam" e muitos os que ouvem, em benefício da dúvida, pode-se pensar que isto indica que muitos entram na comunidade virtual talvez apenas para olhar, “ouvir”. Assim, vale sublinhar que não existe qualquer automatismo entre estar em uma lista, uma comunidade e ter uma participação ativa, o que relativiza bem o escopo das redes digitais, ao não se constatar a disseminação de uma atividade política voraz entre todos os participantes da lista.

Ao se analisar os debates no meio digital entre os participantes do movimento, constata-se uma baixa incidência de referências a partidos e políticos, sendo as energias mais direcionadas para combinar estratégias de atuação nas manifestações de rua, havendo uma "[...] forte tendência a abrandar e evitar conflitos e discussões sobre divergências entre os membros do grupo" (PINHO et al., 2010), conforme já observado. Parece possível detectar que como os participantes eram neófitos em política e em manifestações públicas, mas, por outro lado, como havia uma ligação entre eles (o repúdio ao que o senador Sarney representava), os participantes preferiram manter a convergência em torno desse ponto do que abrir um debate que pudesse fissurar o grupo ao expor as diferenças políticas entre seus participantes.

Assim, o grupo desloca suas energias fundamentalmente para combinar as estratégias das manifestações, principalmente seus aspectos operacionais, tais como, "[...] local de concentração, percurso, adoção de palavras de ordem e cânticos, confecção de cartazes e panfletos, entre outros". (PINHO et al., 2010) Um grande número de mensagens é trocado para combinar todos esses pontos. As passeatas são tratadas como eventos e adquirem caráter de espetáculo.

As mensagens abaixo expressam essa postura. 
eu acho que se queremos visibilidade deveríamos para o trânsito. Não vai adiantar nada se andarmos no passeio e a mídia não divulgar. Acho que isso pode ser pensando na hora, a depender do número de pessoas na hora. (15/08/2009)

Foi ótimo. Atingiu uma boa parte de gente que precisava dar esse apoio que foi dado. O que eu sugiro para a próxima: Avenidas como a Tancredo Neves por ser a avenida mais movimentada em área comercial de Salvador E, claro, não podemos esquecer o Campo Grande. Esse é o início de uma era política se assim desejarmos. Quem fotografou e filmou, vamos organizar um Flick e um Youtube do movimento vendo que a mídia tratou com certo desinteresse essa manifestação popular. Abraço a todos. (15/08/2009)

Bem... Como é sempre bom ter um posicionamento sobre as coisas, aqui vai o meu: achei bem feito. Bem organizado, para nós que somos "os estudantes alienados do século XXI". Não achei que a quantidade foi pouca como o jornalistazinho de merda ficou falando. Se fossem duas pessoas, até uma pessoa só, já era digno de respeito, já seria uma manifestação por seus ideais. Muitos dizem que não vai dar em nada... Pois que não dê. O movimento em si, valeu a pena. Fizemos nossa parte. O meu objetivo era que as pessoas vissem, vissem que em Salvador também tem gente como eles, que não gosta da situação. Que cada garoto da minha idade dentro daqueles carros sentisse vontade de se juntar a nós. Não era que ninguém saísse machucado, que ninguém se ferisse ou algo do tipo, e ainda bem, não foi assim. Vamos pra frente, mostrar que chega de hipocrisia, de gentinha que veste a camisa do Brasil no carnaval e na Copa. Porque eu tenho orgulho do meu país o ano todo, e terei ainda mais se me movimentar para fazê-lo melhorar no que não concordo. Parabéns, gente. Pra todos nós e para todos que participaram do movimento de alguma forma. (15/08/2009)

Galera, gostaria de saber quem está organizando o movimento? Por exemplo, depois da [Avenida] Garibaldi, existe a intenção de nos deslocarmos para algum lugar? Vamos andar no meio da rua para parar o trânsito? Abraços a todos, espero encontrar todos no sábado. (14/08/2009) 
Andar no meio da rua, só funciona com auxilio da polícia ou da reguladora de trânsito. A organização do Movimento FORA Sarney Bahia, em termos de net, está nas mãos do perfil "FORA Sarney Bahia", mas nada monopolizado, porque estamos todos com o mesmo intuito. Basta mandar um e-mail para forasarneybahia@ hotmail.com, ou deixar scrap no perfil (adicionem, quanto mais gente no perfil e na comu, melhor.) que a galera publica as ideias na comu. Obs.: A comunidade é para compartilharmos nossas ideias a respeito do MOVIMENTO, que não será somente marcado por passeatas, faremos, todos juntos, muito barulho através da net. Já se está preparando algo para logo em seguida da caminhada. Manifestem-se e sugestionem. Grande abraço. (14/08/2009)

Agora a semente foi plantada. Esse foi o começo de uma revolta que não vai mais parar! Nos indignaremos e sairemos nas ruas até que a justiça seja feita no nosso país! Até que, não só o Sarney saia, mas também toda essa bandalheira do senado... Todos esses corruptos que ficam aí sugando nosso dinheiro na surdina, que nem um bando de sanguessugas. Chega de sujeira moral, chega de fisiologismo! Fora Sarney e toda a quadrinha do senado! (15/08/2009)

Nessas mensagens, podemos perceber a estratégia dos manifestantes buscando fazer as manifestações em áreas, avenidas movimentadas da cidade, pois o movimento só seria notado se parassem o trânsito. A esse respeito, vale observar que as manifestações ocorreram em dias de fins de semana, e que, assim, os impactos no trânsito são muito menores. Pode-se perceber o entusiasmo dos participantes com os resultados alcançados, observando-se um voluntarismo no sentido de acreditar que os objetivos serão alcançados, ou seja, a cassação de Sarney. É notória também uma crítica à mídia, que não teria dado a devida cobertura ao evento, ou minimizando a importância do mesmo em termos quantitativos de participantes. Percebe-se também que eles sentem que estão dando um exemplo de participação política e é feita certa crítica àqueles que seriam acomodados, ou seja, que só seriam patriotas na hora da Copa e do carnaval. Percebe-se também o cuidado 
em evitar a violência, fenômeno que aconteceria nos movimentos de junho/13, mas, ao que tudo indica, causados pelos Black blocs e não pelos manifestantes.

Assim que uma passeata termina, Pinho e colaboradores (2010) observam que ocorre "[...] uma intensa troca de mensagens em que se congratulam entusiasmadamente pelo sucesso da ação" e já começam os preparativos para a próxima. Os participantes também não deixam de registrar "[...] a repercussão do ato na mídia, normalmente considerada decepcionante". Isso gera uma ambiguidade em relação à mídia tradicional, pois, ao mesmo tempo que a criticam, sentem que dependem dela ao entender que se a manifestação não é noticiada pela mídia, é como se não tivesse existido.

Podemos tirar desses elementos algumas percepções. Mesmo que tenha sido há poucos anos atrás (2009), não havia ainda a intensa troca de mensagens que ocorre no presente através da internet, principalmente com as mídias sociais (Facebook, Twitter). Por outro lado, o objeto das manifestações não motivou a mídia a cobrir os eventos. Por paradoxal que seja, o movimento atraiu mais atenção do Correio da Bahia do que de outros jornais, sendo que este jornal é da família de Antônio Carlos Magalhães, que tinha uma convergência política e ideológica forte com Sarney. Assim, o jornal da família de ACM poderia não ter interesse em divulgar o evento.

Quanto ao papel da mídia, segue mais um depoimento recolhido na comunidade digital.

A TV Bahia nem falou direito da passeata. É por isso que eu a odeio. (15/08/2009)

O que transpira nos debates da comunidade nos leva a perceber que se constrói uma relação com a mídia que é “[...] ambígua, conflituosa - ao mesmo tempo que alguns membros afirmam 'odiar' a mídia, demonstram forte ressentimento diante do pouco destaque dado pelos meios de comunicação às manifestações”. Parece, assim, possível identificar que "[...] estão presos a um círculo vicioso em que o movimento depende de visibilidade na mídia para crescer, mas não consegue crescer porque não consegue visibilidade da mídia”. Assim, 
quando o movimento foi divulgado pelo Jornal da Record com direito a entrevista, o fato é saudado com a afirmação de que "fizemos a diferença”. (PINHO et al., 2010) Por outro lado, quando a mídia deixa de dar destaque, não ao movimento, mas a tudo que cerca o caso José Sarney, isso abala profundamente o movimento.

Outra característica possível de observar é que os debates na comunidade exalam uma visão profundamente negativa da política e dos políticos, em que tudo que se relaciona a isso é visto de forma "[...] extremamente pejorativa, entendidos como sinônimos de corrupção”, sendo a filiação de algum participante a um partido um acontecimento visto como "acusação, ofensa". O grupo recebe com descrédito as menções referentes à filiação partidária, entendendo que os líderes políticos são identificados com "[...] a busca individual por notoriedade, visibilidade". Ao mesmo tempo, demonstram preocupação em virarem "massa de manobra" de pessoas ligadas a partidos. Desta forma, procuram o tempo todo demonstrar e defender a posição de nenhuma identificação com nenhum partido político. Uma das manifestações na rede afirma que no movimento "[...] nãa existe partido, oposição. Há apenas dois lados: os a favor e os contra Sarney". (PINHO et al., 2010) Isto sendo assim, qualquer participante será bem vindo desde que na condição de indivíduo, não de entidades organizadas. Nota-se no debate do grupo esse caráter apartidário do movimento, buscando evitar conflitos e polêmicas. Interessante perceber que esse comportamento se acentuaria nos movimentos de junho/13, mas ao se constatar sua presença em agosto/2009, mostra que isto é uma tendência contemporânea de recusa à política partidária, indicando um desgaste profundo desta, nos moldes tradicionais praticados.

Outra manifestação defende que as divergências partidárias e ideológicas devem ser esquecidas, sendo fundamental "nos concentrar no INIMIGO, não importa se a comunidade engloba petistas, democratas, comunistas, anarquistas, neoliberais, etc. O que realmente importa é a disposição de cada um em derrubar um político desonesto, torpe, nepotista, populista de mentalidade atrasada" [...]. Não vamos gastar energia com nós 
mesmos, vamos combater a ele, pois é ele que combatemos". (PINHO et al., 2010, grifo do autor)

Mesmo quando um participante insiste na ação através da filiação a um partido, os demais participantes desencorajam o debate reconhecendo que "Há o apartidarismo, mas não há omissão política". Um debate que também ocorreu se referiu à questão do debate virtual versus debate presencial. Com constância apareciam sugestões de realização de encontros presenciais entendendo que o Orkut cumpriria um papel de "ferramenta auxiliar", mas não seria "[...] o local apropriado para discutir detalhes da manifestação". Os defensores do ambiente virtual argumentam sobre "[...] as dificuldades de se reunir tantos participantes no meio da rua", onde diferentemente do meio virtual, em que todos poderiam ter acesso ao debate, nem todos poderiam estar presentes, "[...] padecendo assim as decisões de falta de representatividade". No entanto, existem razões mais profundas contra as assembleias presenciais, pois estariam embutindo "[...] o desejo de centralização das decisões nas mãos de alguns membros, que estariam buscando burocratizar o movimento e ganhar notoriedade junto à sociedade". Percebe-se assim que “[...] as divergências políticas vêm à tona, culminando no conflito quando são forçados a 'decidir a forma de decidir'”. (PINHO et al., 2010, grifo do autor)

O acompanhamento do número de adesões no meio digital (Orkut) revela um crescente que atinge 361 (em 17/10/2009), mas entrando logo em decadência registrando 347 (em 29/10/2009), 335 (em 11/11/2009), 324 (em 23/11/2009) e 313 (em 04/12/2009), ainda devendo ser acrescentado que este total de participantes se refere ao meio digital, pois, na prática, nas ruas, a adesão sempre foi bem menor. E o movimento se esvaziou, com a consequente perda de membros, com o arquivamento dos processos contra o senador José Sarney por parte do Congresso, levando a expressões do tipo: “[...] prá que lutar por uma causa que, tecnicamente, já está perdida?”. E, com isso, o movimento se esvaiu, levando a afirmações do tipo: "[...] várias pessoas estão saindo da comunidade" e "parece que o movimento parou. Ou acabou". (PINHO et al., 2010) 
Assim que esta situação se configurou, é postada uma mensagem, certamente de algum membro ou simpatizante do PV, com o sugestivo título: "Eu avisei" (PINHO et al., 2010, grifo do autor), lembrando ter observado que "[...] essa movimentação ia acabar em nada", pois "Não adianta tirar um coronel pois vai entrar outro”. Finaliza conclamando "Entrem em um partido, mostrem suas colocações, perspectivas, ideias inovadoras em gestão pública [...] Saudações Verdes”. Não fica sem resposta esta mensagem, sendo contra argumentado o seguinte: "Amei sua ideia, só faltou escrever uma coisa: E depois vire coronel também”, mostrando de forma compatível com o espírito hegemônico do grupo que entrar na política, nos partidos, representa uma capitulação a suas estruturas viciadas e viciantes. Ao que outro manifestante observa que "Quem tem formação paltada [sic] na ética, moralidade... não entra nesse ciclo...!", defendendo que seria possível encontrar um partido ético. A resposta é uma crítica ao papel dos partidos, quando um participante posta, já nos estertores do movimento ( 28 de novembro), com ironia que "participar de um partido político e se submeter ao sistema, adianta muito. Eu vejo o quanto ações partidárias mudam o Brasil. Em verdade, muda alguma coisa sim, as contas dos cofres públicos”. Esta postagem provoca a seguinte resposta de outro participante: "então, segundo você, temos um problema sem solução. [...] Eu acredito em MUDANÇAS”. Já entrando em dezembro e nas últimas postagens, outro participante assim se manifesta: "Ô, galera. Ser político não significa, necessariamente, desonestidade. Há políticos honestos, por aí, e acho que vocês sabem disso”. (PINHO et al., 2010, grifo do autor) Um participante retorna entendendo como derrota, a "derrota que o povo brasileiro sofreu no senado" e sentindo que "nem vocês, nem os outros conhecem uma solução". Ainda acrescenta que todos ficam perdidos e que, por ficarem "apedrejando uns aos outros, mostram não ter sensibilidade e até mesmo maturidade para buscar uma resposta decente, coerente e justa". (PINHO et al., 2010, grifo do autor) Toda essa discussão reflete bem como a juventude se localiza frente ao sistema partidário do país, revelando um profundo niilismo com relação a este. 
Outra participante expressa que "as pessoas de bem não podem pensar apenas em manifestações [...] elas têm que buscar um meio de mostrar e fazer como se deve ser feito, com ética[...]". Prossegue exemplificando, com várias políticas públicas que não sofrem questionamento, concluindo em letras garrafais (como se estivesse gritando) que "A OMISSÃO PÚBLICA É UM DOS NOSSOS PROBLEMAS”. Esta manifestação não passa em branco, recebendo o comentário: "Existem politicos honestos? Deve existir... Existe partido político honesto? Não! Ha ha. Essa é a diferença, o PT/PC do B já foi tudo que o PSTU/PSOL, PV é hoje, tendência incontestável. A corja prevalece, o dinheiro manda e faz girar o mundo. Prefiro me manter apartidário". Esta postagem faz emergir um questionamento sucinto: “Alienação é a solução?” (PINHO et al., 2010, grifo do autor) obtendo uma longa resposta (em 19/12) que finaliza a comunidade na rede:

Mister [nome fictício], não é coerente desqualificar este movimento. Foi um movimento espontâneo, nada mais político! A questão não é de como iria acabar este movimento, o fato mais relevante é que ele começou, ele surgiu. A luta política nos partidos é um caminho, claro... Mas não seja legalista, a política nasceu antes e independentemente de partidos políticos. A voz do cidadão, como influente na sociedade, seja como consumidor, como crítico, como eleitor ou como político é igualmente relevante. Este movimento não quis lutar em favor de uma posição-proposta política específica. Mas isso não é motivo para que ele seja classificado como sem sentido. Ao contrário, foi um movimento, ao meu ver, em favor da política democrática ou, melhor, do espaço democrático na política e, por isso, é automaticamente contrário a ações como a do nosso querido senador. O movimento, como disse certa vez nessa comunidade, não tem o sentido de resolver os problemas da política brasileira, depondo um presidente do senado, não. Esta deposição é só uma ação direta e visivel. A bandeira do movimento é maior, ela diz respeito, como disse, à ética na política, ela diz respeito à participação dos jovens e demais cidadãos na política. E a própria existência deste movimento já foi significativa em todos esses sentidos. Antes de desqualificar, devemos fazer o possivel pra que este movimento não morra. O brasileiro precisa entender que a política o atinge e que 
ela não deve ser um mundo à parte do que ele vive e nem que seu papel de cidadão se finde com a votação tampouco com a filiação a um partido. (PINHO et al., 2010, grifo do autor)

Sintetizando, parece possível abrigar a análise feita da comunidade e do movimento em quatro grandes compartimentos: 1) visão profundamente negativa da política partidária, tentando manter a posição apartidária do movimento, levando, inclusive, ao limite de recusar a participação de filiados a partidos políticos; 2) forte tendência a abrandar e evitar conflitos e discussões sobre divergências entre os membros do movimento; 3) forte ambiguidade em relação à mídia tradicional, pois, por um lado, criticavam a posição da mídia ao não registrar ou não dar a devida cobertura às manifestações, por outro lado, sentindo a necessidade de que isso acontecesse, que o movimento só seria viável se vazasse para a mídia convencional; 4) não havia exatamente um líder, algum participante que se destacasse e chamasse para si a responsabilidade do movimento, o que, em parte, o aproxima do MPL, nesse quesito. Por não ter um interlocutor explícito, uma liderança que se sobressaísse, essa característica pode ter levado o movimento ao fracasso.

Notar que, nos protestos de 2013, o grupo que comandava o MPL já tinha uma tradição de organização e mobilização construída em manifestações anteriores. O grupo que constitui o FS se constrói para aquele momento, não tinha qualquer tradição ou experiência em realizar manifestações e se dissolve com o arquivamento da denúncia contra Sarney, ou seja, são dois movimentos e grupos com constituições radicalmente diferentes. Cabe uma última palavra mais de ordem metodológica sobre a análise dessa material. A coleta das manifestações da própria comunidade no meio digital mostra-se bastante positiva, pois são colhidas as palavras dos participantes. Na metodologia da análise do meio presencial, o que acontece nas ruas, embora possa se recolher elementos mais concretos (a violência, gestos, o vestuário, etc.), faltam palavras, ainda que estas possam estar presentes nos cartazes, embora estáticos. 


\section{A REVOLTA DO VINTÉM}

Nesta seção, será feita uma breve descrição do que foi a chamada Revolta do Vintém ocorrida no Rio de Janeiro. Para tanto, vamos recorrer, basicamente, à análise efetuada por Ronaldo Pereira de Jesus que se valeu de pesquisa detalhada em jornais da época. Ela teve origem na instituição do "imposto do vintém" ainda no Império anunciado em dezembro de 1879 , para entrar em vigor em $1^{\circ}$ de janeiro de 1880. O imposto tinha como objetivo conter o déficit do reinado, através da cobrança de um vintém (que correspondia a 20 réis, a moeda da época) sobre o valor das passagens dos bondes no Rio de Janeiro, capital do Império. A partir do anúncio do imposto, "[...] mobilizações de protesto foram encabeçadas por publicistas e políticos, especialmente os republicanos, em geral membros dos setores médios urbanos" que visavam a capitalizar "[...] o descontentamento generalizado da população mais humilde da corte, assolada pela carestia, pelo desemprego, pelas precárias condições sanitárias e pela falta de moradia”. Ainda antes da entrada em vigor do novo imposto, "[...] uma multidão se reuniu para expressar, em praça pública, seu descontentamento com a medida governamental" devido o baixo nível de vida da maioria da população da cidade. Foram contidos e dispersados pela força policial ao tentarem entregar ao imperador um manifesto de repúdio ao novo imposto. As manifestações coletivas de protesto duraram de 28 de dezembro de 1879 a 4 de janeiro de 1880 , enfeixando o que veio a ser conhecido como a Revolta do Vintém. Buscando uma explicação teórica para o evento, Ronaldo Pereira de Jesus (2006, p. 73-74) recorre à Sandra Graham, que descreve os participantes que

[...] mesmo estando em certa medida afastados das instâncias partidárias, teriam se convertido numa 'fonte de poder até então nunca utilizada', capaz de transformar a 'violência da rua' em parte da 'equação política' e, assim, 'arrastar a política das salas do parlamento para as praças da cidade'.

Olhando mais de perto a própria construção do imposto, ainda em fase de discussão, a imprensa já se mostrava contra o novo imposto, 
apresentando o argumento de que este incidiria de "[...] modo indiscriminado sobre cidadãos e súditos com rendimentos desiguais”, não fazendo distinção entre "[...] um rico comerciante que habitava uma chácara em Botafogo, ou um operário humilde residente num casebre na Cidade Nova". A isto se adicionava o argumento de que a população rica procurava os bairros mais afastados por "prazer ou luxo", enquanto que os mais pobres procuravam os "[...] bairros mais distantes, em geral mais insalubres" por conta dos preços mais baixos de aluguel. E para este grupo, o transporte por bonde era indispensável para chegar ao centro da cidade. Assim, "[...] às vésperas do Natal de 1879, o imposto do vintém era considerado por toda imprensa como uma medida extremamente impopular". Nesse clima e com uma "[...] intensa circulação de boatos a respeito de uma grande manifestação popular" marcada para a data de início da cobrança do imposto, “[...] alguns jornais começaram a pedir 'calma' e 'reflexão' para aqueles decididos em contestar as medidas do governo". (JESUS, 2006, p. 75) Se do ponto de vista da imprensa esta era sua posição, do ponto de vista governamental é editada uma nota, logo após o Natal, proibindo "reuniões públicas” bem como "manifestação da liberdade de expressão", colocando em alerta as forças policiais da corte, o que veio a gerar alertas da imprensa situacionista contra "a intransigência do poder público". Apesar de todas essas medidas, uma primeira manifestação pública contra o imposto ocorreu em 28 de dezembro, quando "[...] cerca de cinco mil pessoas se reuniram no Campo de São Cristovão para ouvir o Doutor Lopes Trovão", um médico e jornalista e ativo militante republicano e abolicionista, que falou à multidão da janela de um sobrado, defendendo levar uma petição ao imperador, solicitando a revogação do imposto. Liderada pelo orador, a multidão se deslocou em direção ao Paço da Boa Vista, onde se encontrava o imperador. No deslocamento, foi "intimado" a interromper a jornada por delegados e "[...] mais de cem agentes armados de longos e grossos cacetetes", o que levou Lopes Trovão a “[...] não ceder às intimidações, justificando se tratar de uma mobilização pacífica”. (JESUS, 2006, p. 77) O imperador, no entanto, não aceitou receber os manifestantes, se dispondo, mais tarde, a 
receber apenas uma comissão, mas esta se recusou a aceitar a decisão tardia do imperador. Registre-se que, assim, não ocorreu violência na manifestação, ainda que tenha ficado latente. O mesmo não ocorreu dias depois com a implantação do novo imposto e quando o movimento de protesto passaria "[...] a incluir outros segmentos da população carioca menos 'ordeiros' e a 'civilidade' no episódio da tentativa de entrega da petição ao imperador ficaria definitivamente para trás”. No primeiro dia do ano de 1880 , ainda que algumas empresas de bondes não estivessem cobrando do vintém e que Lopes Trovão conclamasse a população "[...] a resistir pacificamente à cobrança do imposto" em discurso no Largo do Paço, as pessoas reunidas se deslocaram pelas ruas do centro da cidade entre "[...] vaias e manifestações de descontentamento", chegando até estações de bondes, iniciando-se "[...] a depredação dos bondes e o conflito direto com as forças policiais". (JESUS, 2006, p. 78)

Havia "uma lógica quase idêntica" de protesto nas várias ruas, qual seja, “[...] os manifestantes tomavam os bondes, espancavam os condutores, esfaqueavam os animais usados como força de tração, despedaçavam os carros, retiravam os trilhos e, com eles, arrancavam as calçadas”. Com os destroços, faziam barricadas respondendo à polícia “[...] com insultos, pedradas, garrafadas e até com tiros de revólver". Ao longo desse dia, primeiro do ano, a polícia respondia aos vários focos de protesto, “[...] quase sempre atirando contra a multidão". Os conflitos só foram encerrados às 21 horas, com o resultado de três manifestantes mortos e feridos, “[...] a maior parte por arma de fogo". No dia seguinte, face ao resultado produzido, construiu-se uma tentativa de acordo com o governo, tanto por parte dos políticos mais conservadores como pelos publicistas "mais exaltados" contra o imposto. No entanto, nas ruas, o protesto tinha seguimento, "[...] já sem o apoio de seus principais idealizadores" e o governo se posicionando que estaria disposto a negociar, mas que não admitiria a quebra da ordem pública e nem a formação "grandes massas de povo" frente ao palácio imperial (JESUS, 2006, p. 79-80). No que se refere ao sepultamento das vítimas, afirmava que não fossem feitas manifestações como as feitas por 
ocasião da Revolução Francesa. Interessante notar que passado quase um século da revolução em França, esta parecia estar pairando como uma ameaça aos monarquistas.

Já no dia 2 de janeiro, novas manifestações irromperam, sendo dispersas pela Polícia e sendo várias pessoas presas. No dia seguinte, o número de escaramuças se reduziu, dia em que senadores e deputados da oposição, contando com a participação de Lopes Trovão, José do Patrocínio e outros se reuniram para redigir "[...] um manifesto contra o vintém” e conclamando o povo à paz e à ordem. No dia 4 de janeiro, com "[...] cerca de cem pessoas reunidas no Largo de São Francisco, foram abordadas pela força policial e responderam com pedradas, pauladas e garrafadas", a maioria deles caixeiros das casas comerciais do centro da cidade. Neste dia, termina a Revolta do Vintém, a partir de “[...] relações estabelecidas entre as classes populares da corte e o Estado monárquico", “[...] depois de interrompida a arrecadação pelo protesto popular". No dia seguinte, um importante jornal, Jornal do Commercio, arrolava os principais segmentos sociais presentes nas manifestações: "[...] a juventude das escolas, cheia de nobre, mas indefinido entusiasmo por tudo o que lhe agita a fibra sensível das generosas paixões", ao lado dos que se sentiam prejudicados pela política dominante, sem exatamente sem nomear quais eram. Todos estes pertenciam "[...] aos setores médios urbanos e à elite da corte”. (JESUS, 2006, p. 81-82) Ao lado destes, agregava o jornal, vinha o "segmento popular" visto pelo jornal como aquele que

[...] na sinceridade de sua crassa ignorância e sob o agulhão das privações diurnas, estão sempre prontos a condenar os governos, sejam quais forem, que não realizem o ideal impossível e sobrenatural de dirigirem a sociedade de modo que não pague impostos e que todas vivam contentes no seio de uma abundância fácil e sem trabalho. (JESUS, 2006, p. 82)

Por outro lado, "publicistas e políticos antimonarquistas atribuíam as causas da Revolta do Vintém à impopularidade do regime imperial e ao desgaste da imagem de D. Pedro II entre a maior parte da população da cidade do Rio de Janeiro". Encerrados os conflitos, isto não viria a 
provocar "grandes alterações" na Monarquia nem na figura do Imperador para a maioria da população. Encerra Pereira de Jesus, afirmando que

a Revolta do Vintém ocasionou muito mais a alteração radical e momentânea das atitudes e expectativas diante do regime político e do Imperador, do que uma mudança significativa e duradoura no imaginário popular, nas representações das pessoas comuns acerca da Monarquia. (JESUS, 2006, p. 87)

\section{ANÁLISE DOS MOVIMENTOS E CONCLUSÕES}

Feita essa exposição de elementos básicos para compreensão desta Revolta, passamos agora para uma tentativa de análise de aproximação ou diferenciação entre os movimentos acima analisados. Desnecessário enfatizar que existe um abismo de tempo e condições entre a última década do Império, e penúltima do século XIX, e os movimentos recentes de 2009 e 2013. Em que pesem essas diferenças explícitas, algumas convergências chamam a atenção. Em primeiro lugar, a questão do transporte parece mobilizar as populações. Conforme assinalado ao início deste artigo, no transporte é que a população sente, de forma direta e imediata, o "assalto" ao seu bolso. Ainda que possa encontrar uma alternativa ao pagamento com o deslocamento a pé, isso nem sempre é possível, ainda mais em uma cidade grande onde horários são impostos à classe trabalhadora bem como a estudantes. Assim, uma parcela da população se torna escrava do transporte coletivo, população esta expulsa para a periferia, quer seja no final do regime monárquico, quer seja mais de um século depois em períodos autoritários ou democráticos. Uma segunda questão também merece destaque, exatamente a participação de uma população jovem formada por estudantes, o que vem a se repetir nos dois outros movimentos focados.

Merece ainda atenção o fato de que a tão cantada passividade da população brasileira parece vir por terra quando se analisa, principalmente, essa Revolta do Vintém. Evidentemente, o ambiente é bem quente do ponto de vista político com a emergência do movimento republicano 
e também abolicionista. Assim, a luta não era pelos 20 Réis (1 vintém), mas tinha um forte conteúdo político de minar a autoridade da Monarquia e do Monarca. Mas, também, todas essas manifestações têm que ser olhadas com cautela, pois, ao mesmo tempo que a sociedade explode, parece que se recolhe a uma outra longa hibernação voltando a explodir. Ou seja, parece que a sociedade se comporta espasmodicamente, com sístoles e diástoles. Também Pereira de Jesus observa que a Revolta do Vintém também não representou o abalamento do regime monárquico, com a ordem estabelecida se recompondo. Observa, ainda, que superada a Revolta do Vintém, o Império ainda leva quase dez anos para cair, e quando isto acontece, a massa urbana assiste a tudo "bestializada", conforme registrado por José Murilo de Carvalho (1987), não tendo noção de que ali se consumia a implantação da República.

Parece que esta tem sido a tendência dominante no Brasil no largo prazo. Ao se observar os movimentos mais representativos das últimas décadas, conforme já apontado, após os movimentos das Diretas Já (1984), tivemos os Caras Pintadas (1992), e os movimentos de junho/13, isto quer dizer, uma explosão a cada década ou mais. Assim, os movimentos têm que ser saudados com importância e ânimo, mas sem grandes expectativas de que tudo vai mudar e rapidamente. No caso desses últimos movimentos, vale observar que sendo "Estopim dos protestos de junho de 2013 pelas ruas do país, a discussão sobre tarifa e qualidade do transporte coletivo nas regiões metropolitanas não atingiu em cheio a campanha presidencial" (GERARQUE; MONTEIRO, 2014), sendo que esta campanha se deu pouco mais de um ano depois dos protestos, dando a impressão de que havia saído da pauta.

Em outra esfera, vale comentar que, evidentemente, à época da Revolta do Vintém não havia os recursos digitais existentes agora, mas houve uma mobilização impressionante em uma sociedade ainda escravocrata, onde a palavra democracia não reverberava, não tinha qualquer acolhimento. O Rio de Janeiro, com uma população que pode ser estimada em cerca de 400 mil habitantes (247.972 pelo Censo de 1872, e 522651 pelo Censo de 1890, segundo o IBGE) consegue mobilizar, naquele contexto, cerca de 5 mil pessoas para manifestações que 
duram quatro dias seguidos, mostra que existem formas de mobilizar as massas que transcendem as comunicações digitais. Este artigo enfatiza este aspecto, pois existe uma tendência muito forte, atualmente, de imputar as tecnologias o fato das participações políticas. Não desprezando, evidentemente, o poder que estas têm de levar o cidadão às ruas não é só questão de comunicação, conforme já apontado no quadro teórico.

Quando se coteja o FS com o junho/13, já se nota, evidentemente, uma aproximação maior e mais facilmente identificada, principalmente no que se refere às tecnologias de comunicação, embora também neste quesito, apesar do pouco tempo decorrido entre um e outro, já exista um finado, o Orkut, superado pelas redes sociais mais potentes e interativas. Outra diferenciação também tem que ser feita. A apropriação do que foram esses movimentos foi feita de maneira diferenciada. Se no caso do FS acompanhou-se o movimento "por dentro", ainda que no ambiente digital, no caso do Junho/13, foi feita pelos registros da imprensa e por construções teóricas de analistas políticos. Ainda outra diferenciação merece ser apontada: o caso do FS tinha um foco específico, perseguia a remoção, a cassação do senador Sarney, enquanto o Junho/13, como sabemos, tinha, a princípio, um foco no questionamento do aumento de passagens, explodindo, em seguida, para uma pauta ampla e diversificada de questionamentos e demandas, todas na área política.

A capacidade de mobilização do FS, não apenas no caso acompanhado de Salvador como em outras capitais do Brasil, capacidade muito menor do que a identificada no Junho/13, pode apontar que mobilizações contra a corrupção parecem difíceis de emplacar, não motivam as populações como se estivessem a ver que estão batalhando por uma causa perdida, enquanto que no caso do Junho/13 a luta pela tarifa era mais concreta, ainda que tenha derivado para essa agenda pluri, conforme apontado.

Outra convergência pode ser apontada entre esses dois movimentos recentes, a participação intensa de jovens, mas principalmente jovens de classe média e média alta, estudantes em parte considerável do 
nível médio. Se isso pode ser saudado como positivo, também preocupa no sentido de uma inclusão não tão forte de um público universitário. Também foi observado que existe uma fuga às formas tradicionais de fazer política e filiação a partidos políticos. Se esta é uma tendência mundial, do mundo ocidental principalmente, por razões sobejamente conhecidas, isto se agrava no Brasil, com todo o desalento com a política, os políticos e os partidos políticos.

Para encerrar, a análise acima, se transpira certo pessimismo, isto deve ser relativizado. Por um lado, no sentido de evitar cair em uma euforia não consistente. A partir da máxima de que não existe "almoço grátis", pode-se contrapor que "não existe revolução grátis” ou, se não se almeja tanto, "não existem mudanças grátis". Assim, o papel de todos esses movimentos coletivos tem que ser valorizado no sentido da construção de uma sociedade mais justa e igualitária no Brasil, mas sem cair na tentação de que tudo vai ser alcançado fácil e automaticamente.

Ainda uma inquietação que esta análise gera. A política parece estar sendo permeada pelas redes. Quando os próprios manifestantes diziam em junho/13 para sair do Facebook, da internet e vir para as ruas, evidentemente se sabe que não dá para ficar nas ruas o tempo todo, mas existe um risco (risco?) de que os jovens voltem às redes até outro despertar, até por entender que esta é a maneira mais fundamental e decisiva de se fazer política. Uma última reflexão, acima já arranhada, cabe à questão: por que algumas manifestações pegam e outras não pegam? Alguns analistas têm apontado que, diferentemente do que pregavam os manifestantes, a manifestação não era pelos vinte centavos. o que se assistiu foi que, assim que a demanda da revogação do aumento das passagens foi atendida, o movimento recuou e se esvaziou. E a longa pauta que "pegou carona" no movimento da MPL, praticamente não foi atendida, ressalvada, em parte, como dito, a questão da saúde com o "Mais médicos". Como vários autores usaram a metáfora da fagulha, faísca e estopim, podemos pensar nos movimentos como uma caixa de fósforos, onde nem todos que são riscados funcionam. 


\section{REFERÊNCIAS}

AGRE, P. Criando uma cultura da internet. Revista USP. São Paulo, n. 35, set./nov. 1997. Dossiê Informática/Internet.

CARVALHO, J. M. O Rio de Janeiro e a República que não foi. Rio de Janeiro: Cia das Letras, 1987.

CASTELLS, M. A Sociedade em Rede. São Paulo: Paz e Terra, 1999.

CASTELLS, M. Internet e sociedade em rede. In: MORAES, D. (Org.). Por uma outra comunicação: mídia, mundialização cultural e poder. Rio de Janeiro: Record, 2003. Cap. 11.

CASTELLS, M. A galáxia da internet: reflexões sobre a internet, os negócios e a sociedade. Rio de Janeiro: Zahar, 2003.

CASTELLS, M. Redes de indignação e esperança: movimentos sociais na era da internet. Rio de Janeiro: Zahar, 2013.

ECO, U. Entrevista. “O Professor Aloprado”, Folha de São Paulo, São Paulo, 11 maio 2008.

GERAQUE, E.; MONTEIRO, A. Não é por R\$o,20, Folha de São Paulo, São Paulo, 23 set. 2014. Eleições 2014, p. A8.

FORASARNEY. In: WIKIPÉDIA a enciclopédia livre. Português. 2009. Disponível em: <http://pt.wikipedia.org/wiki/Forasarney>. Acesso em: 10 maio 2014 .

GOHN, M. da G. As manifestações de junho de 2013 e os movimentos sociais. Disponível em: <http://www.unipress.blog.br/as-manifestacoesde-junho-de-2013-e-os-movimentos-sociais-por-maria-da-gloria-gohn/>. Acesso em: 22 jan. 2015 .

IASI, M. L. A rebelião, a cidade e a consciência. In: MARICATO, E. et al. Cidades rebeldes: Passe Livre e as manifestações que tomaram as ruas do Brasil. São Paulo: Boitempo: Carta Maior, 2013.

IBOPE. Pesquisa IBOPE sobre as Manifestações em 8 capitais. 20 jun. 2013.

JESUS, R. P. de. A Revolta do Vintém e a Crise na Monarquia. História Social, Campinas/SP, n. 12, p. 73-89, 2006. 
KUCINSKYI, B. Informática e liberdade. In: SANTOS, L. et al. Revolução tecnológica, internet e socialismo. São Paulo: Ed. Fundação Perseu Abramo, 2003. p. 59-82. (Coleção Socialismo em Discussão).

LIMA, V. A. de. Mídia, rebeldia urbana e crise de representação. In: MARICATO, E. et al. Cidades rebeldes: Passe Livre e as manifestações que tomaram as ruas do Brasil. São Paulo: Boitempo: Carta Maior, 2013. LÖWY, M. Entrevista. Estado de São Paulo, São Paulo, 29 dez. 2013. MAMEDE-NEVES, M. A. et al. Problemas e valores apontados por jovens universitários pertencentes a sociedades emergentes: um estudo sobre a Barra da Tijuca. Revista de Comunicação, Cultura e Política, Rio de Janeiro, v. 4, n. 7, p. 164-195, jul./dez. 2003.

MARICATO, E. É a questão urbana, estúpido! In: MARICATO, E. et al. Cidades rebeldes: Passe Livre e as manifestações que tomaram as ruas do Brasil. São Paulo: Boitempo: Carta Maior, 2013.

MARTINS, J. de S. A política no Brasil: lúmpen e místico. São Paulo: Contexto, 2011.

MARTINS, J. de S. A pauta escamoteada. Estado de São Paulo, São Paulo, 29 dez. 2013, Caderno Aliás.

MOVIMENTO PASSE LIVRE. Não começou em Salvador, não vai terminar em São Paulo. In: MARICATO, E. et al. Cidades rebeldes: Passe Livre e as manifestações que tomaram as ruas do Brasil. São Paulo: Boitempo: Carta Maior, 2013.

NOGUEIRA, M. A. As ruas e a democracia: ensaios sobre o Brasil Contemporâneo. Brasília, DF: Fundação Astrojildo Pereita; Rio de Janeiro: Contraponto, 2013.

PESCHANSKI, J. A. O transporte público gratuito, uma utopia real. In: MARICATO, E. et al. Cidades rebeldes: Passe Livre e as manifestações que tomaram as ruas do Brasil. São Paulo: Boitempo: Carta Maior, 2013.

PINHO, J. A. G. de. Investigando portais de governo eletrônico de estados no Brasil: muita tecnologia, pouca democracia. RAP, Rio de Janeiro, v. 42, n. 3, 2008. 
PINHO, J. A. G. de. Sociedade da informação, capitalismo e sociedade civil: reflexões sobre política, internet e democracia na realidade brasileira. RAE, São Paulo, v. 51, n. 1, jan./fev., 2011.

PINHO, J. A. G. de et al. Internet e democracia: uma investigação preliminar do movimento Fora Sarney em Salvador no Orkut. Mimeo. 2010 .

RHEINGOLD, H. La comunidad virtual: uma sociedade sin fronteiras. Barcelona: Gedisa Editorial, 1996.

ROLNIK, R. Apresentação: as vozes das ruas: as revoltas de junho e suas interpretações. In: MARICATO, E. et al. Cidades rebeldes: Passe Livre e as manifestações que tomaram as ruas do Brasil. São Paulo: Boitempo: Carta Maior, 2013.

SANTOS, L. G. Debate com o público. In: SANTOS, L. G. et al. Revolução tecnológica, internet e socialismo. São Paulo: Ed. Fundação Perseu Abramo, 2003. p. 59-82. (Coleção Socialismo em Discussão).

SECCO, L. As Jornadas de Junho. In: MARICATO, E. et al. Cidades rebeldes: Passe Livre e as manifestações que tomaram as ruas do Brasil. São Paulo: Boitempo: Carta Maior, 2013.

SINGER, A. Brasil, junho de 2103: Classes e ideologias cruzadas. Novos Estudos. CEBRAP, São Paulo, n. 97, nov. 2103.

SORJ, B.Brasil@povo.com: a luta contra a desigualdade na sociedade de informação. São Paulo: Zahar; Brasília: Unesco, 2003.

VAINER, C. Quando a cidade vai às ruas. In: MARICATO, Ermínia et al. Cidades rebeldes: Passe Livre e as manifestações que tomaram as ruas do Brasil. São Paulo: Boitempo: Carta Maior, 2013. 